\title{
四阿火山：成層火山体の開析地形とその利用*
}

\section{Dissected geomorphology of the Azumaya Volcano and its application*}

\section{竹下欣宏 ${ }^{1}$ 西来邦章 ${ }^{2}$ 富樫 均 $^{3}$}

\section{Yoshihiro Takeshita ${ }^{1}$, Kuniaki Nishiki ${ }^{2}$ and Hitoshi Togashi ${ }^{3}$}

2015 年 2 月 16 日受付.

2015 年 5 月 12 日受理.

日本地質学会第 122 年学術大会 $(2015$ 年・長野) 巡検 (4 班) 案内書

1 信州大学学術研究院教育学系

Institute of Education, Shinshu University, 6-ro, Nishinagano, Nagano 380-8544, Japan

2 産業技術総合研究所活断層 - 火山研究部門 Institute of Earthquake and Volcano Geology, Geological Survey of Japan, AIST, Tsukuba Central 7, 1-1-1 Higashi, Tsukuba, Ibaraki 305-8567, Japan

3 長野県環境保全研究所自然環境部

Natural Environment Division, Nagano Nature Conservation Research Institute, 2054120, Kitago Nagano 381-0075, Japan

Corresponding author: Y. Takeshita, takey@shinshu-u.ac.jp

(注) 本原稿のカラー版 PDF が J-STAGE でご覧い ただけます。「巡検案内書」の冊子掲載に関わる 詳細は, 本誌 p.261 を参照して下さい.

\section{概 要}

當阿火山は長野・群馬県の県境に位置し, 約 80 万年前〜 45 万年前にか けて活動した大型の成層火山である. 環状に連なる稜線によって囲まれた “四阿カルデラ”と呼ばれる直径 $3 \mathrm{~km}$ ほどの凹地が，地形的な特徵である. このカルデラから流れ出る米子川の上流域には, 厚さ $150 \mathrm{~m}$ に達する溶岩 層が作る断崖絶壁が約 $1 \mathrm{~km}$ も続き, 不動滝や権現滰をはじめとする落差 70〜80 m ほどの複数の滝が見られる. また, カルデラ内には硫黄鉱床が存 在し，1960(昭和 35) 年まで米子硫黄鉱山として採掘が続けられた。このほ か周辺には, 中世の山岳修験道に由来をもつ米子不動奥之院や但唱上人が 木食行を行ったと伝えられる遺跡も存在する. 本コースでは, 四阿カルデラ, 不動滝や権現滝といつた成層火山体の開析地形とそれらを構成する火山岩 類を観察するとともに, 米子硫黄鉱山跡や米子不動奥之院といった人文的 景観についても見学する.

\section{Keywords}

四阿火山, 成層火山, 開析地形, 四阿カルデラ, 米子硫黄鉱山, 米子の滝 Azumaya volcano, stratovolcano, dissected geomorphology, Azumaya caldera, Yonako Sulfur Mine, Yonako-no-taki

\section{地形図}

$1: 25,000$ 「四阿山」,「須坂」

\section{見学コース}

$\mathrm{JR}$ 長野駅 $\rightarrow$ 須坂市野辺 $\rightarrow$ 米子の滝駐車場 $\rightarrow$ 不動滝 $\rightarrow$ 権現滝 $\rightarrow$ 権現沢上流 (登山道沿い) $\rightarrow$ 米子硫黄鉱山跡 $\rightarrow$ 鉱山事務所跡 $\rightarrow$ 米子 の滝駐車場 $\rightarrow$ JR 長野駅

\section{見学地点}

Stop $1 \quad\left(36^{\circ} 38^{\prime} 18^{\prime \prime} \mathrm{N}, 138^{\circ} 18^{\prime} 59^{\prime \prime} \mathrm{E}\right)$ 須坂市野辺臥竜橋(百々川)：四阿火山周辺の地形・地質

Stop $\left.2 （ 36^{\circ} 34^{\prime} 5^{\prime \prime} \mathrm{N}, 138^{\circ} 24^{\prime} 16^{\prime \prime} \mathrm{E}\right)$ 不動滝 : 米子溶岩と米子凝灰角砅岩

Stop $3\left(36^{\circ} 34^{\prime} 5^{\prime \prime} \mathrm{N}, 138^{\circ} 24^{\prime} 21^{\prime \prime} \mathrm{E}\right) \quad$ 不動寺裏の登山道(Short stop)：権現滝の遠望

Stop $4 \quad\left(36^{\circ} 34^{\prime} 2^{\prime \prime} \mathrm{N}, 138^{\circ} 24^{\prime} 26^{\prime \prime} \mathrm{E}\right) \quad$ 大黒沢・権現沢間の登山道 : 四阿カルデラと地すべり地形

Stop $5\left(36^{\circ} 33^{\prime} 56^{\prime \prime} \mathrm{N}, 138^{\circ} 24^{\prime} 22^{\prime \prime} \mathrm{E}\right) \quad$ 権現沢 : 熱水変質带と廃坑から流出する酸性水

Stop $6 \quad\left(36^{\circ} 34^{\prime} 16^{\prime \prime} \mathrm{N}, 138^{\circ} 24^{\prime} 23^{\prime \prime} \mathrm{E}\right)$ 米子硫黄鉱山跡：硫黄鉱床と米子大瀑布遠望

Stop $7 \quad\left(36^{\circ} 34^{\prime} 22^{\prime \prime} \mathrm{N}, 138^{\circ} 24^{\prime} 24^{\prime \prime} \mathrm{E}\right) \quad$ 米子硫黄鉱山事務所跡 : 四阿カルデラと米子溶岩 


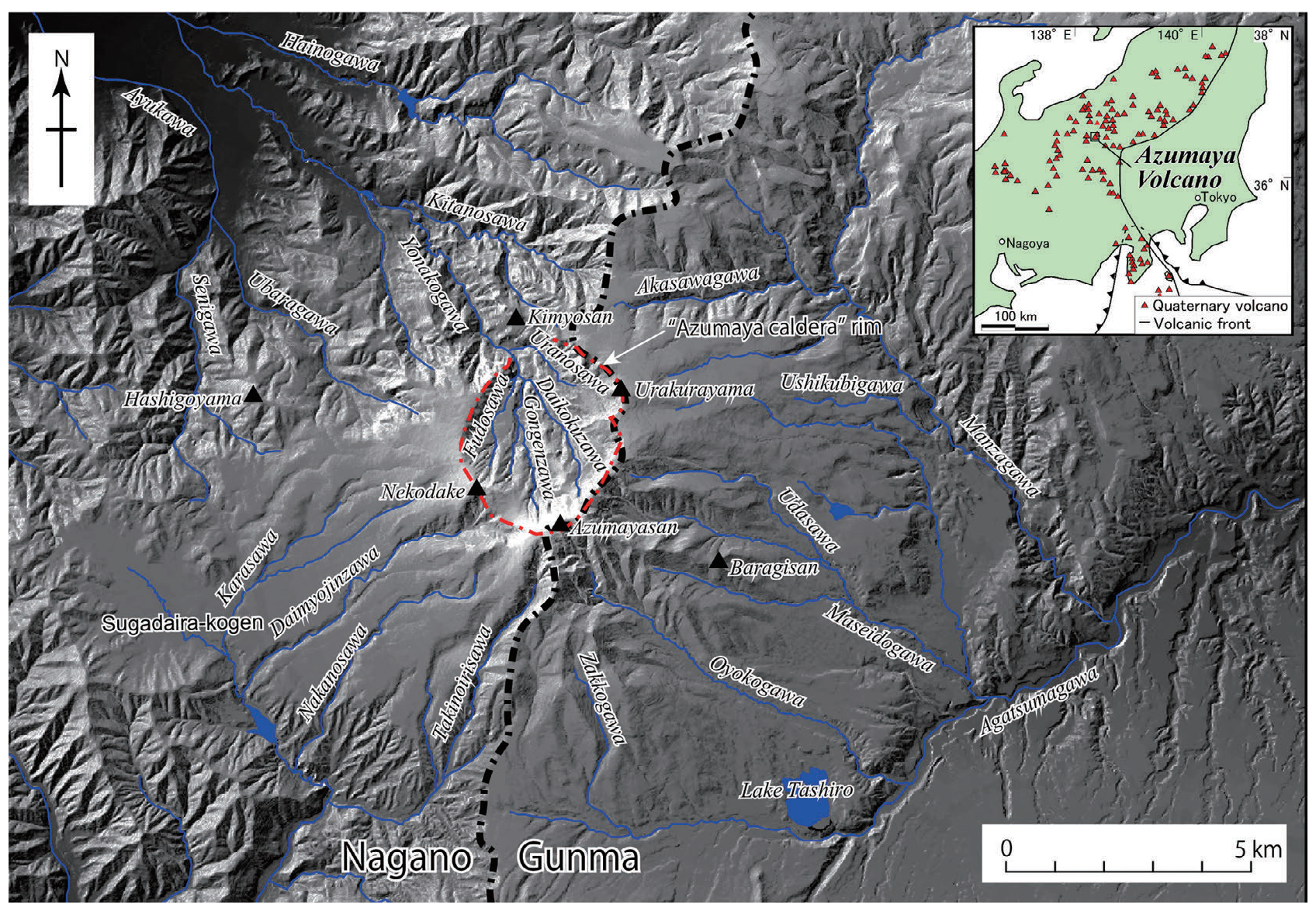

第 1 図. 四阿火山の位置と地形. 第四紀火山の分布は中野ほか (2013)による. 陰影図には北海道地図株式会社の GISMAP (10 m メッシュ数值標高データ)を用いた．赤点線は“四阿カルデラ”の縁を示す.

Fig. 1. Index and relief map of Azumaya volcano and surrounding area. The distribution of Quaternary volcanoes is after Nakano et al. (2013). The relief map was created using GISMAP (10-m-mesh digital elevation data) released by Hokkaido Chizu Co. Ltd. The red dashed line shows the rim of "Azumaya caldera".

\section{は じめに}

㐭ず阿火山は長野・群馬県の県境に位置し(Fig. 1), 約 80 万年前 45 万年前に活動した大型の成層火山である (金子ほ か, 1989; 西来ほか, 2014). 浦倉山(2,091 m), 四阿山 $(2,354 \mathrm{~m})$, 根子岳 $(2,207 \mathrm{~m})$ を含む山頂域の稜線が環状に 連なり，それによって囲まれた“四阿カルデラ”と呼ばれる直 径 $3 \mathrm{~km}$ ほどの凹地が, この火山の地形的特徵となっている (Figs. 1, 2). “四阿カルデラ”という名称は, 八木(1941)に よりはじめて使用され，その後，嬬恋村誌編集委員会編 (1977), 塩野入 (1983), 小林ほか(2011)などでも用いら れている. “四阿カルデラ”の成因については, 本間(1931) 以降，八木(1941), 太田・片田(1955)などで大爆発火口, 爆発力ルデラという言葉が用いられていることから, 古くは 爆発的噴火が成因であると考えられてきたようであるが，い ずれの研究にもカルデラを生じさせた噴出物などの根拠とな る記載はない。その後, “四阿カルデラ”は, 四阿專原軽石 の噴出による陥没カルデラ(荒牧・早川, 1996)あるいは山頂 部の崩壊による地形(西来ほか, 2014) と指摘されたが，現在 のカルデラ状の地形と蒿原軽石の噴出源との関係は明らかに
されておらず，崩壊イベントによる堆積物も今のところ発見 されていない。“四阿カルデラ”という名称は, すでに市町村 誌や地域の地形・地質を紹介する普及書でも用いられ広く浸 透しているため, これを四阿火山山頂部に見られる直径 $3 \mathrm{~km}$ ほどの凹地を指す地名として用いる.

“四阿カルデラ”から米子川が流れ出る付近(標高 1350 $1500 \mathrm{~m}$ )には, 厚さ $150 \mathrm{~m}$ に達する溶岩層が作る断崖絶壁 が約 $1 \mathrm{~km}$ も続き, 落差 70〜80 m ほどの複数の滝が見られ る(Fig. 3)。これらのうち, 不動滝と権現滝(Fig. 4)は, 「米子の滝」と呼ばれ古くから親しまれてきた. 1890 (明治 33) 年に発表された森鴎外の「みちの記」や 1925 (大正 15) 年 に長野電鉄株式會社により作成された「長野電車名勝案内」に も「米子の滝」との名称が登場する. さらに, この 2 条の滝 は, 1990 年に日本の滝百選に選ばれ「米子大瀑布」と呼ばれ 全国的に知られるようになつた。滝の幅や流量がさほどでな いにも関わらず，大瀑布と呼ばれる所以は，落差が大きいこ とだけでなく, 滝のかかる岩壁とその後方に悠然と広がる “四阿力ルデラ”が組み合わさって生み出される壮大な景観に 負うところが大きい.

“四阿力ルデラ”内の火山岩類は広く熱水変質作用を被って 


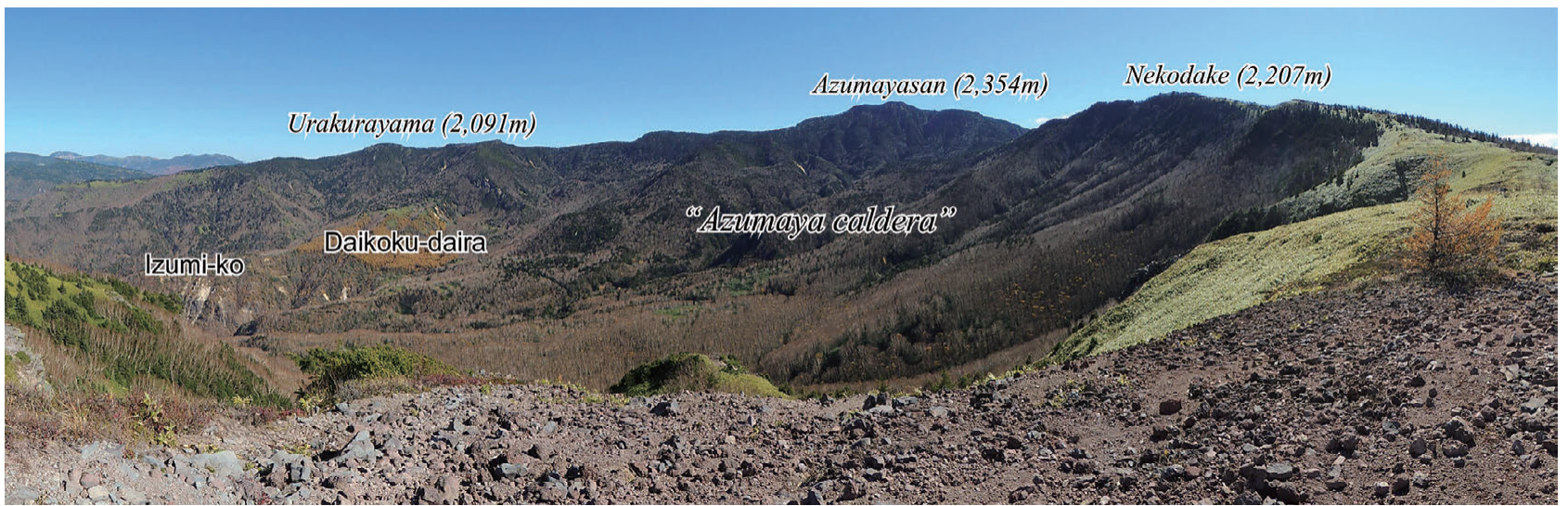

第 2 図. 根子岳北方から望む四阿カルデラの全景. 撮影地点を第 10 図に示す.

Fig. 2. Photograph of "Azumaya caldera", viewed from north of Nekodake. The viewpoint is shown in Fig. 10.

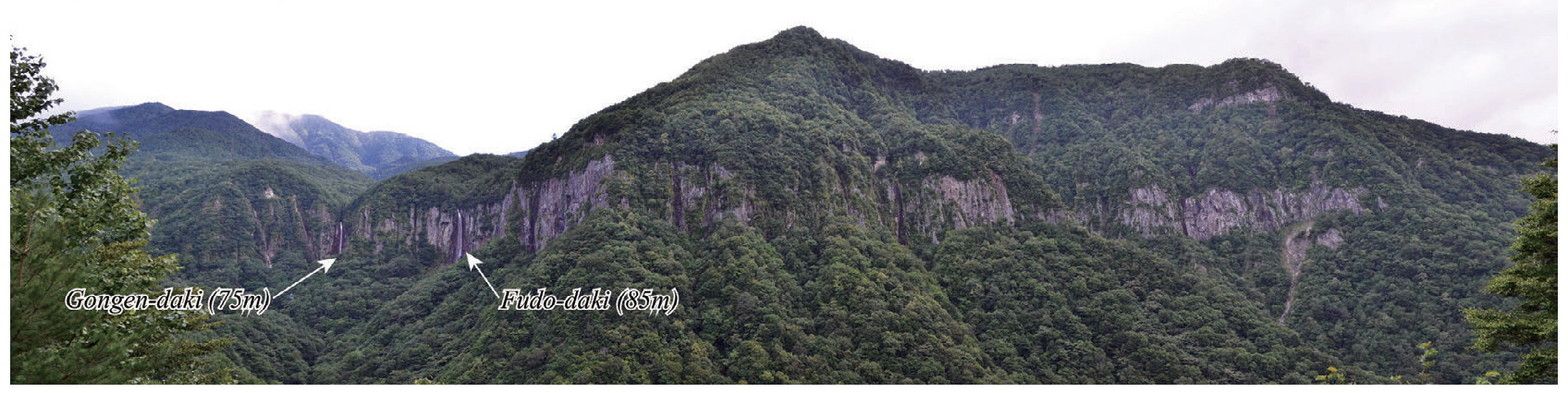

第 3 図. 米子溶岩層が形成する岩壁。撮影地点を第 10 図に示す

Fig. 3. Cliffs formed by the Yonago lavas. The viewpoint is shown in Fig. 10.

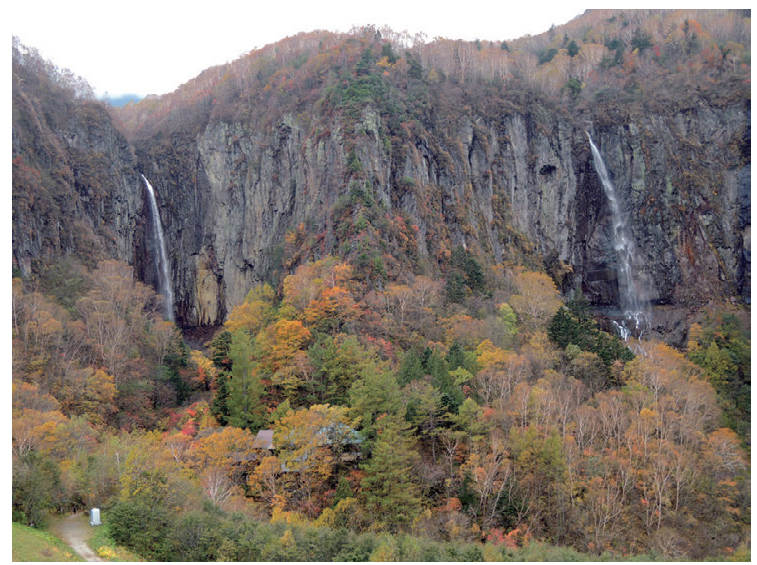

第 4 図. 米子の滝 (左，権現滝 ; 右，不動滝).

Fig. 4. Yonako Great Waterfalls. Left, Gongen daki; right, Fudo daki.

おり，米子川上流の大䆀滰を中心とする一帯に硫黄鉱床が 存在する(太田・片田, 1955)。この鉱床は 1960 (昭和 35) 年まで米子硫黄鉱山として採掘が続けられた。この鉱山は, 寛永年間 (1630 年代)に近江の治兵衛が硫黄の採掘をはじめ たとの記録が残るが，さらにさかのぼる可能性も指摘されて
いる(宮澤, 2014)。また，不動滝の下流右岸には，中世の山 岳修験道に由来をもつ米子不動奥之院があり, 鎌倉時代初 期の仏師運慶系の作とされる不動明王が本尊として祀られ る.このほかにも, 米子川右岸の奇妙山平と呼ばれる緩斜面 には, 但唱上人が木食行を行ったと伝えられる遺跡が残る (宮澤, 2014). 以上のように不動滝と権現滝を含む“四阿力 ルデラ”一帯は, 成層火山体の開析によって生夕出された壮 大な自然景観を呈するだけでなく, 産業と信仰を通して古く から人が関わってきた人文的景観の要素も多分に包含してい る.

これまで“四阿カルデラ”の成因は詳しく検討されていな かったが, “四阿カルデラ”とその周辺の地形, 地質, 溶岩層 の年代值を整理したところ, 米子川による激しい下方侵食と 大規模な熱水変質帯における地すべりの相互作用が，“四阿 カルデラ”を形成した主な要因である可能性が示唆された. 今回の巡検では, “四阿カルデラ”および「米子の滝」の成り立 ちを中心に，米子硫黄鉱山跡や米子不動奥之院といつた人文 的景観にも目を向け，成層火山体の開析地形と人の関わりに ついて実感していただくことを本コースの目的とする.

\section{地形・地質概説}

四阿火山西方に位置する長野盆地ば善光寺平とも呼ばれ, 


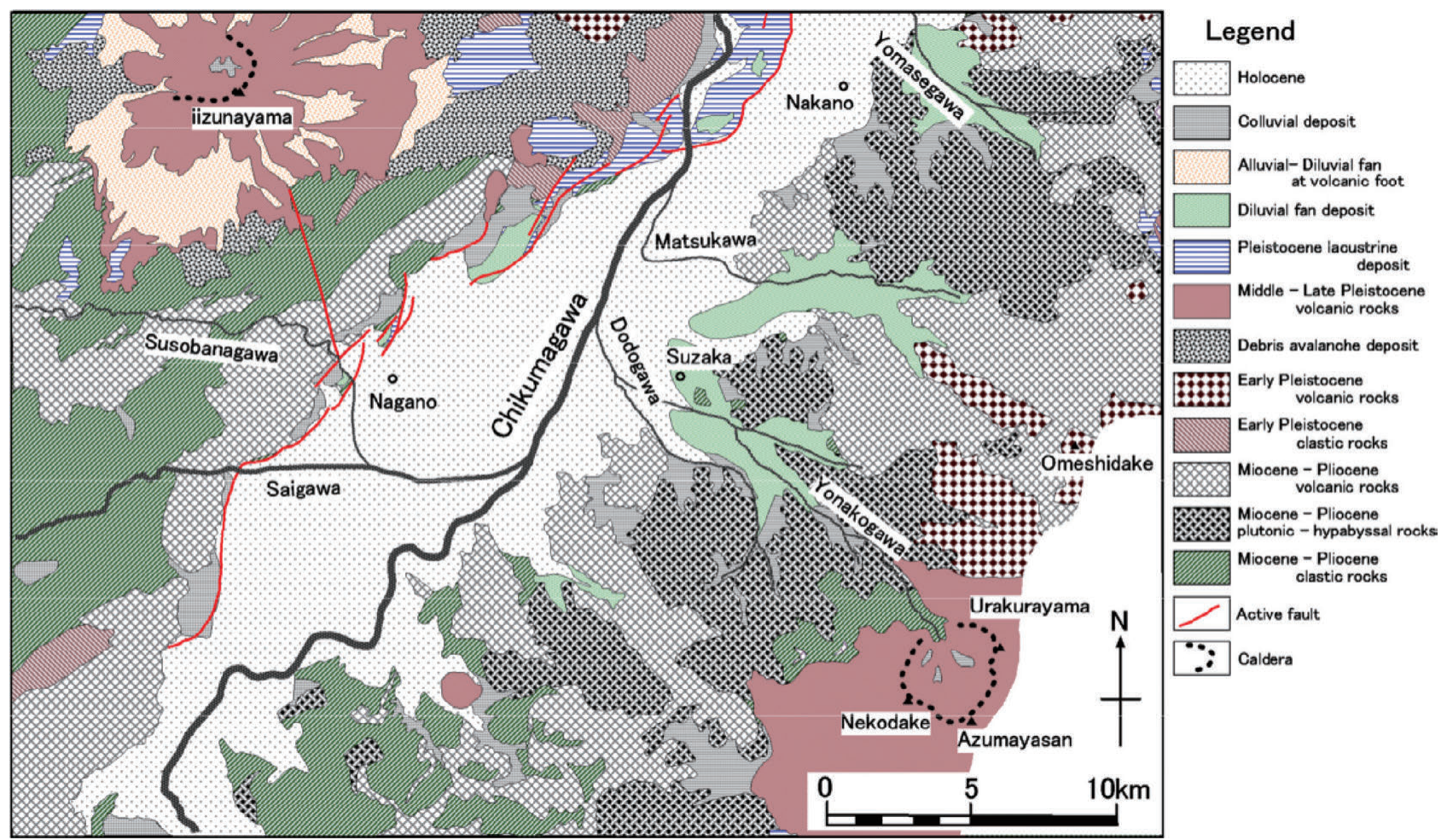

第 5 図. 四阿火山周辺の地質図. 新版長野県地質図作成委員会編 [URL]をもとに，許可を得て簡略化し再編集した.

Fig. 5. Geological map of the area surrounding Nagano Basin including Azumaya volcano (modified after Editorial Committee of the New Geological Map of Nagano Prefecture, [URL]).

千曲川中流域の長野市を中心に，幅約 $10 \mathrm{~km}$, 長さ約 $40 \mathrm{~km}$ (下流の飯山盆地を除く場合) の低平地をもつ北東南西方向へ 細長くのびた内陸盆地である. 盆地の西には西山 (水呙丘陵) と呼ばれる標高数百 $\mathrm{m}$ から千数百 $\mathrm{m}$ の山々が, 東には標高 千数百 $\mathrm{m}$ から $2000 \mathrm{~m}$ 級の山々からなる河笨山地(三国山 脈の一部)が対峙する. 四阿火山を含む長野盆地周辺地域の 地質概略図を Fig. 5 に示す. 山地の地質構成は, 千曲川を 境に東と西で大きく異なる。西山は主に中新世から中期更新 世にかけて北部フォッサマグナに堆積した海成 (一部は汽水 成から湖沼成) の砕屑岩類や海底火山噴出物等の地層から構 成されており，それらを基盤にして，中期更新世以降に陸上 で活動した飯縄(綱) 火山・黑姫火山などの火山(妙高火山群 など)が南北方向に並ぶ(加藤・赤羽, 1986; 長森ほか, 2003; 早津，2008). 飯縄火山・黒姫火山の山頂付近には直径 2 $1.5 \mathrm{~km}$ の北西側に開いた小カルデラが認められ，そのカル デラ開口部の下方には岩首なだれ堆積物が分布する(早津, 2008)。一方, 四阿火山を含む東側の河東山地は, 一部に中 新世の海成層が分布するものの, 大半は中新世〜中期更新世 にかけて形成された深成岩類〜半深成岩類と中新世〜後期更 新世の火山岩類の分布で占められる (太田・片田, 1955; 中 野ほか, 1998; 赤羽・竹下, 2011). 地形的にみると, 長野 盆地平坦部の西縁は北東南西方向の直線的な急崖の連続で画 されているのに対し, 東縁は壮年期の侵食山地の複数の尾根 が，岬のように盆地内に張り出す形状を示す (Fig. 5)。これ ら東西の地形の対照的な違いは, 盆地の形成史に密接に関
わっている. 加藤・赤羽(1986)によれば, 盆地北西縁には 長野盆地北西縁構造線と呼ばれる活断層带 (長野盆地西縁活 断層帯)があり, 最新の断層活動とともに盆地に対して相対 的に西側の山地が隆起している. 一方, 東側の河東山地は, 中期中新世以降の隆起帯ないし非沈降帯であり, 現在は北西 方向に傾動している. 河東山地の西麓斜面には深成岩や半深 成岩が広く露出することや, 山体の奥まで深い䛦が刻まれて いることから, 河東山地が西山よりも長期にわたる隆起と激 しい侵食を受けてきたことがわかる. また河東山地が更新世 以降に盆地側へ傾動していることは, 大きな谷の出口に更新 世の扇状地が広がり，その扇状地面がより急勾配で完新統の 扇状地面に接し, さらにその下に埋没している様子によく表 れている(Fig. 5).

四阿火山は, 北部フォッサマグナで認められる火山フロン トの屈曲部付近に位置し, その周辺には浅間・鳥帽子・草津 白根・御飯火山など前期〜中期更新世以降に活動した第四 紀火山が多く分布する (中野ほか, 2013)。とくに長野と群馬 の県境(上信国境)をなすほぼ南北の稜線沿いには新旧の火山 砕屑岩や溶岩類が密に分布し, ところどころ強く熱水変質を 受けて粘土化するとともに，それらを母岩とした硫黄鉱床が 高密度で形成されている。この地域一帯では近世の時代から 複数の硫黄鉱山が開かれ, 昭和の初期から昭和 30 年代にか けての最盛期には, 数千人規模の鉱山の町も形成された. し かし時代とともに硫黄の生産技術が大きく様変わりし, 昭和 40 年代までの稼行を最後に, 現在ではすべてが閉山してい 

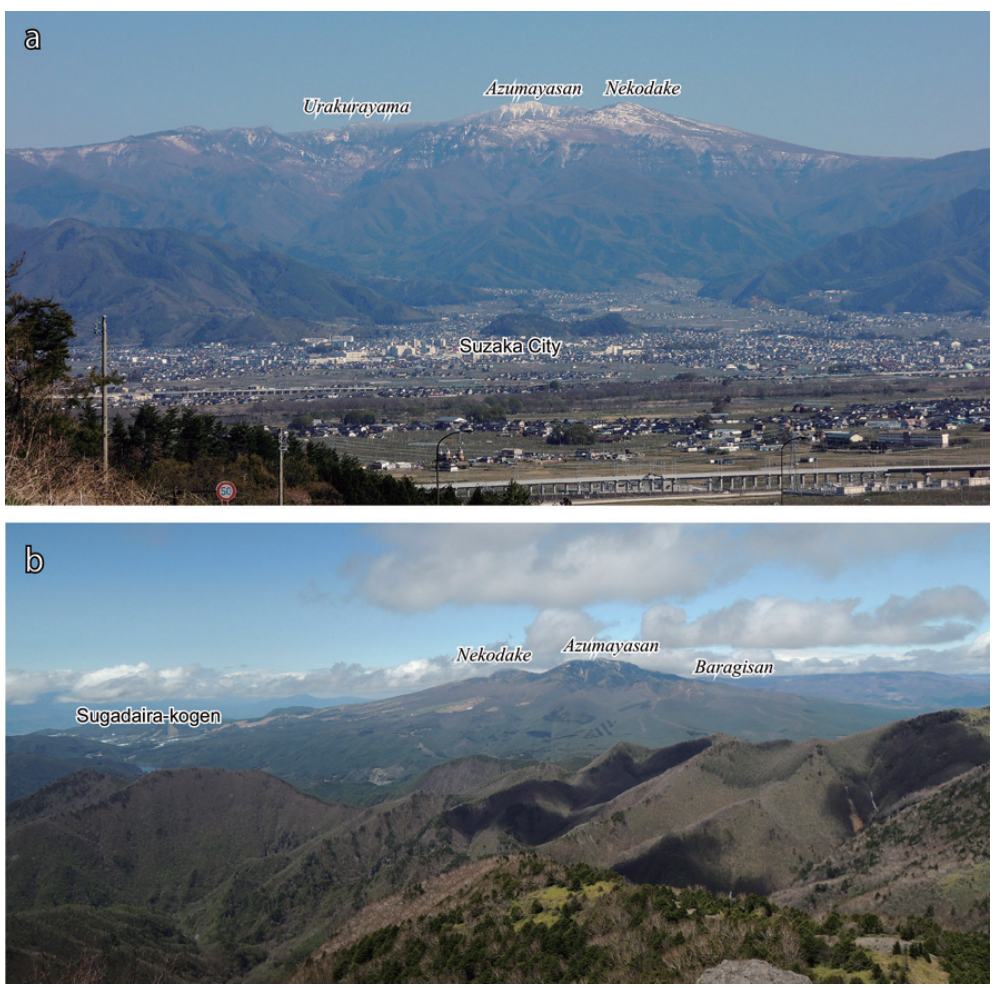

第 6 図. 四阿火山の山容. a) 北西側 (長野市若槻 西条), b) 南側 (鳥帽子岳).

Fig. 6. Photographs of Azumaya volcano, viewed a) from the northwest of the volcano (Wakatsuki-Nishijo, Nagano city), and b) from the south of the volcano (Ebosi-dake).

る. かつて米子川上流の四阿火山のカルデラにあつた米子鉱 山は，その代表的なもののひとつである.

四阿火山の山腹には大小多くの谷があり，山頂域から放射 状に沢が流れ出している，それらは四阿山山頂と北の浦倉山 を結ぶ稜線を境に，日本海へそそぐ千曲川水系と太平洋へと 注ぐ利根川水系に大別される，利根川水系に比べ千曲川水系 の河川の方が，深く険しい谷を刻んでいる(Fig. 1)。千曲川 水系の河川のうち，米子川は“四阿カルデラ”内部の水を集 め，北西側の長野盆地へと流れ出している，米子川が“四阿 カルデラ”から外へ流れ出る付近では，比高が $100 \sim 150 \mathrm{~m}$ の絶壁が連続し，不動滝と権現滝をはじめとする多くの滝が かかる(Fig. 4). カルデラ内には米子川の源流部である不動沢,

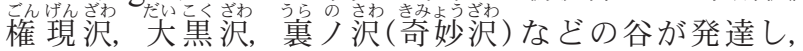
谷頭を山頂付近までのばしている.

四阿火山の西〜北側には梯子山 $(1,513 \mathrm{~m})$ をはじめ，基盤 岩類が標高の高いところまで分布しており (Fig. 5), それら の古い地質体に阻まれて成層火山特有の緩やかな広い裾野は あまり発達しない(Fig. 6a)，一方の南〜東側では基盤岩は 露出せず標高 $1,000 \mathrm{~m}$ 付近まで四阿火山の噴出物が分布し, 根子岳の南西側や浦倉山の東側に成層火山特有の緩やかな広 い裾野が発達する(Fig. 6b)。これに対して四阿山の南東 側は, 大横川や馬洗井户川によって侵食され, 茨菜山一带 はやや開析が進んでいる (Fig. 1)。四阿火山の地質と活動史 については次項で記述する.

\section{四阿火山の活動史}

四阿火山は，噴出物の分布と活動年代，地形の開析の程度 から，約 80 万年前〜 55 万年前に活動した初期火山体，約
70 万年前 65 万年前に活動した根子岳火山体，約 50 万年 前〜 45 万年前に活動した浦倉山火山体に分けられる (西来ほ か, 2014).また，北関東に分布する中期更新世テフラのう ち, 四阿火山起源とされているテフラは, 四阿㝨原軽石層 (Az-Mip : 矢口・田辺, 1990; 町田・新井, 2003), 菅平第 2 軽石 (Az-SgP.2 : 鈴木・早川, 1990)の少なくとも 2 枚が 知られており，それらの年代は層位学的に Az-Mip が約 25 万年前 (町田・新井, 2003), Az-SgP.2 は約 24 万年前 (大石, 2009) と推定されている. ここでは, 西来ほか(2014)に従 い, 四阿火山の火山活動史を述べる. この火山の地質図を Fig. 7 に，噴出物の層序関係を Fig. 8 に示す.

初期火山体は, “四阿カルデラ”付近を噴出中心として約 80 万年前に形成を開始した火山体である. 約 80 万年前頃 には, 米子溶岩層の厚い溶岩流が流出し, 主たる山体が形成 された。 また，それとは独立に田代湖周辺で山体が形成され た (小池山溶岩層の活動)。約 75 万年前には, 主たる山体に おいて大谷溶岩層と茨木溶岩類の溶岩流と火砕物が噴出し, さらに, 約 70 万年前には, 神川溶岩層, それ以降に四阿溶 岩類の溶岩流と火砕物が噴出し, 約 55 万年前まで活動が継 続した.

根子岳火山体は，根子岳〜菅平高原の緩斜面を形成した火 山体である. 約 70 万年前 65 万年前に, デイサイト質の 亲方石溶岩層と根子岳溶岩類の溶岩流と溶結した火砕物が 初期火山体の西斜面に噴出し形成された。本火山体は，初期 火山体の活動期間中に近接した場所で形成しているが，この デイサイトの $\mathrm{Rb} / \mathrm{Y}$ 比は, 初期火山体の噴出物と比べて有 意に高いことから (Fig. 9), 初期火山体の側火山ではなく別 個の火山体として扱われている (西来ほか, 2014)。根子岳火 


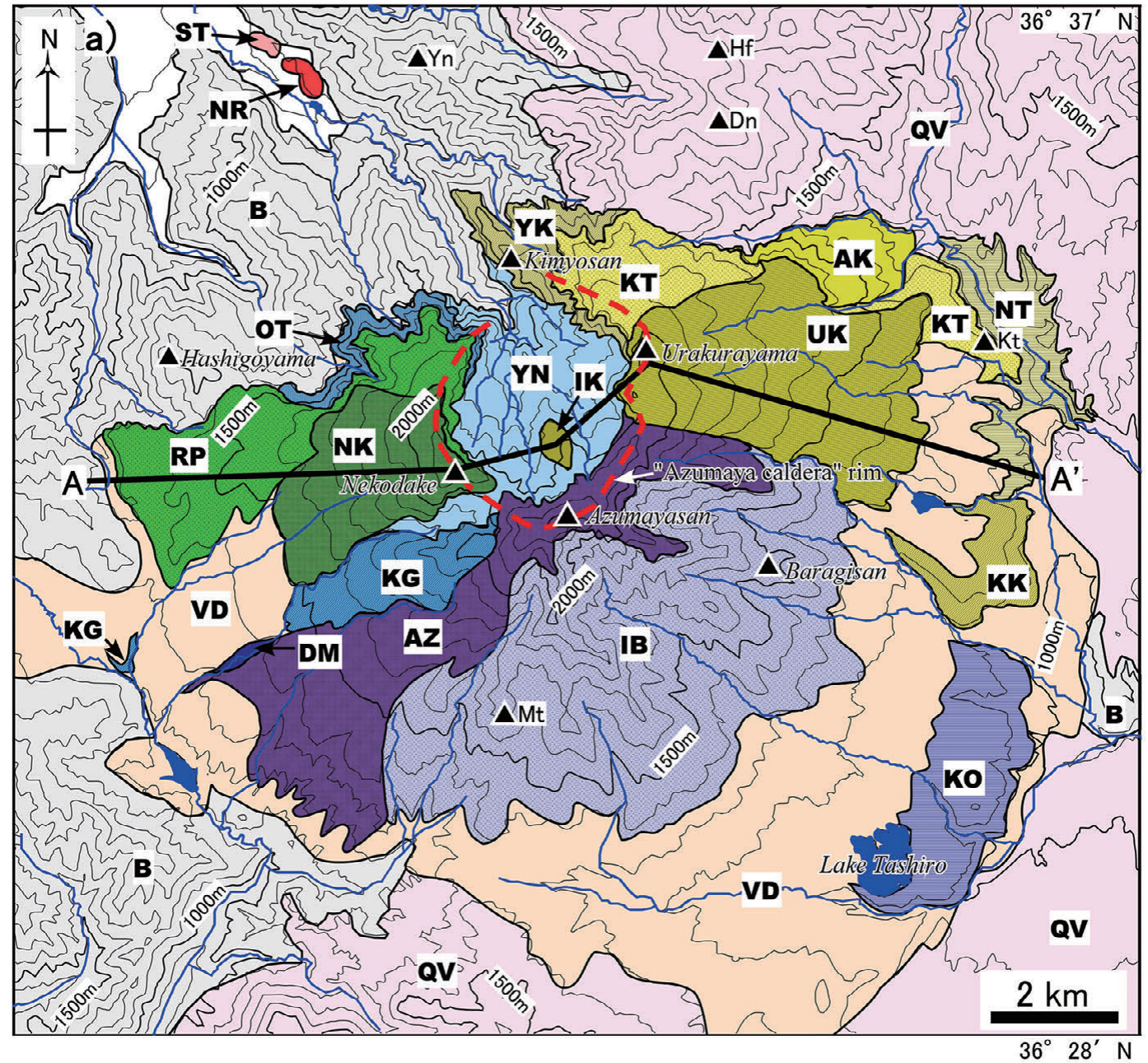

\section{b) (m)}

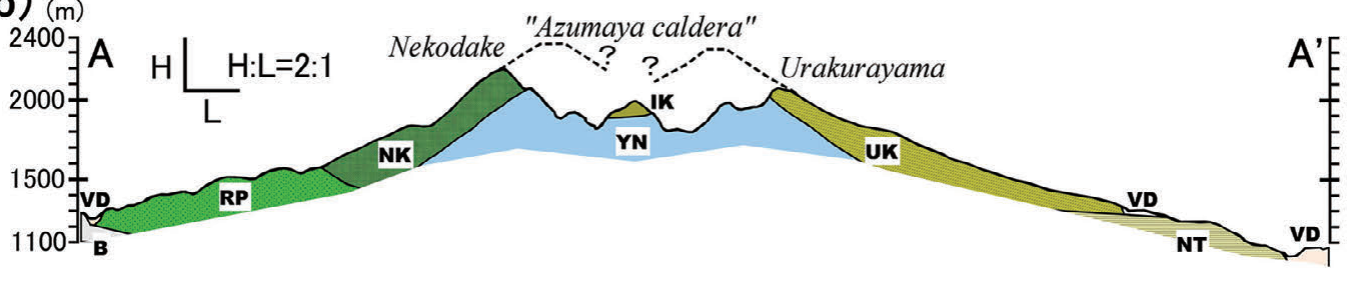

\section{LEGEND \\ Naruiwa volcano \\ NR Naruiwa lavas \\ ST Satomiya lava}

\section{Azumaya volcano}

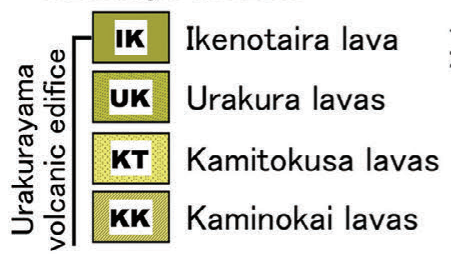

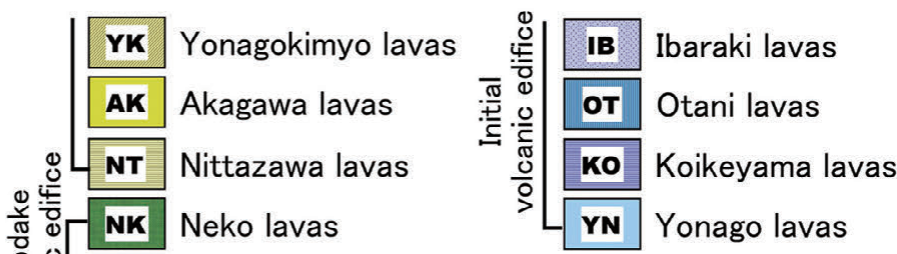

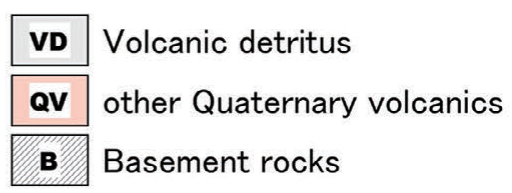

第 7 図. a) 四阿火山および鳴岩火山の地質図. 西来ほか (2014)の Fig. 2 に加筆修正. 略号：Yn，米子山；Hf，破風岳；Dn， 土鍋山；Kt，上砥草山；Mt，的岩山。 b) A-A’地質断面図 (西来ほか, 2014)。赤点線は“四阿カルデラ”の縁を示す.

Fig. 7. a) Geological map of Azumaya and Naruiwa volcanoes (modified from fig. 2 in Nishiki et al., 2014). Red dashed line shows the rim of "Azumaya caldera". Abbreviations: Yn, Yonakoyama; Hf, Hafudake; Dn, Donabeyama; Kt, Kamitokusayama; Mt, Matoiwayama. b) Cross-section along the line A-A' shown on the geological map (Nishiki et al., 2014). 


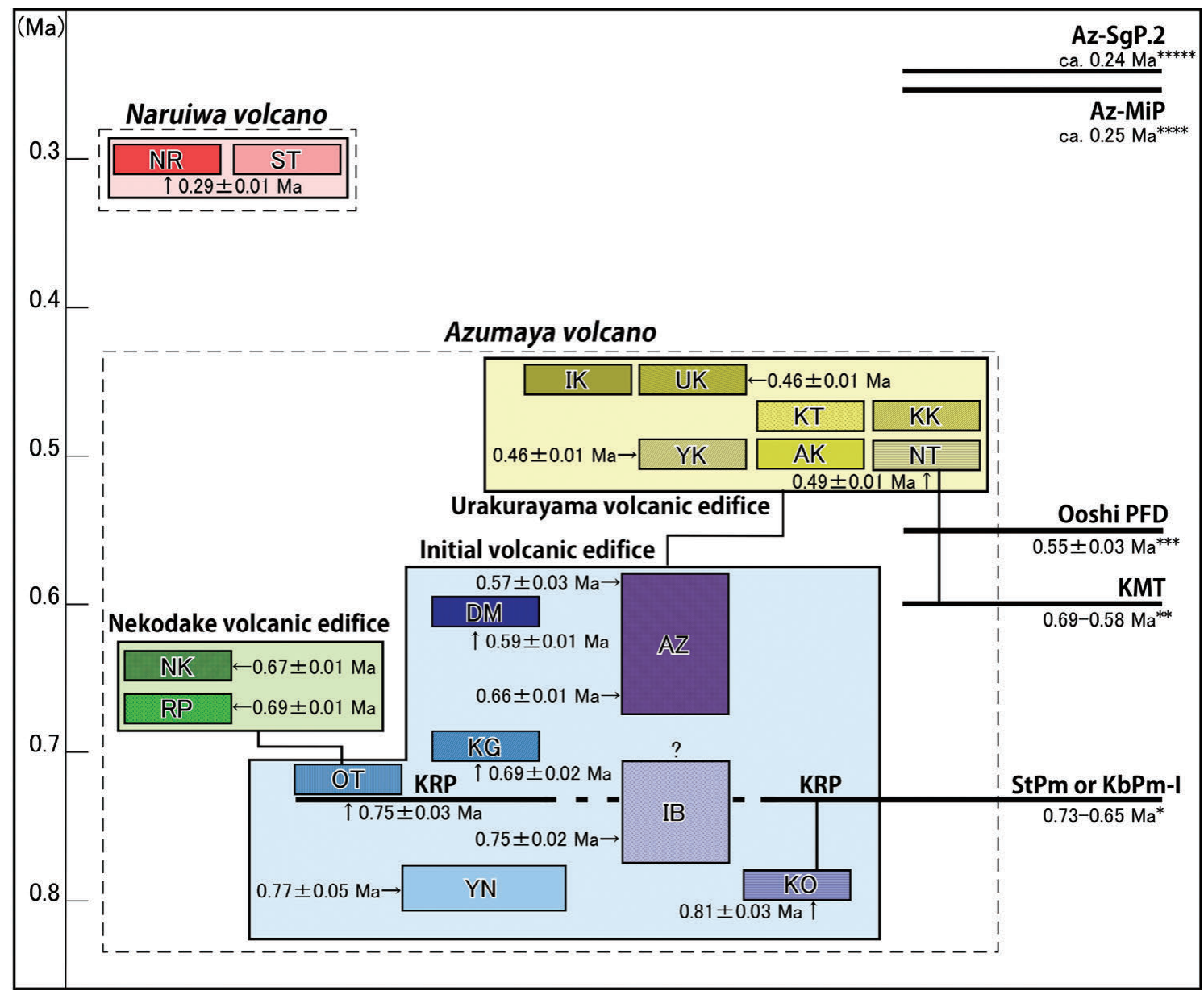

第 8 図. 四阿火山および鳴岩火山の地質層序. 西来ほか (2014)の Fig. 3 に加筆修正. テフラ及び火砕流堆積物の年代は, *Kioka et al. (1998), ** 鈴木 (2000), ***金子ほか (1989), **** 町田・新井 (2003), *****大石 (2009)による. 溶岩名の略号 は第 7 図と同じ. 略号:KRP, クリパミス (田辺・上信火山団体研究グループ, 1992); StPm, 里宮パミス (松本盆地団体研究グルー プ, 2002); KbPm-I, 寒原パミス I(松本盆地団体研究グループ, 2002); KMT, 貝塩上宝テフラ(鈴木, 2000); Az-MiP, 四阿㝨原軽 石層 (矢口・田辺, 1990); Az-SgP.2, 菅平第 2 軽石層 (鈴木・早川, 1990).

Fig. 8. Stratigraphy of Azumaya and Naruiwa volcanoes (modified from fig. 3 in Nishiki et al., 2014). The ages of the tephra and pyroclastic flow deposits are from the following sources: * Kioka et al. (1998), ** Suzuki (2000), *** Kaneko et al. (1989), **** Machida and Arai (2003), and ***** Oishi (2009). Abbreviations of geological units are the same as in Fig. 7. Other abbreviations: KRP, Kuri Pumice (Tanabe and Collaborative Research Group for Jo-Shin Volcanic Terrain, 1992); StPm, Satomiya Pumice (Matsumoto Basin Collaborative Research Group, 2002); KbPm-I, Kambara Pumice I (Matsumoto Basin Collaborative Research Group, 2002); KMT, Kaishio Kamitakara tephra (Suzuki, 2000); Az-MiP, Minohara Pumice bed (Yaguchi and Tanabe, 1990); Az-SgP.2, Sugadaira Dai2 Pumice bed (Suzuki and Hayakawa, 1990).

山体は，初期火山体よりも早期に活動を停止したにも関わら ず, 初期火山体と比べて開析があまり進んでいない(Fig. 7). この違いについては, 根子岳火山体は溶岩や溶結火砕岩で構 成される緩斜面からなるのに対し, 初期火山体は急峻で溶岩 と火砕岩で構成されることから, 侵食抵抗力に違いがあった こと, あるいは根子岳火山体と同じ流域(神少市に合流する水 系)の四阿溶岩類については開析の程度が小さいことから, 水系の違いによる侵食基準面の違いなどがその要因として考 えられる(西来ほか, 2014)。

浦倉山火山体は, 浦倉山〜嬬恋高原の緩斜面を形成した 火山体である. 初期火山体の活動終了後, 5 万年程度の活動 休止期を挟んだ約 50 万年前に，仁苗沢溶岩層や上㔔貝溶岩 層が浦倉山付近から東方へ流出した。 また，北方へは米子
奇妙溶岩類が流出した. 約 45 万年前には, 浦倉溶岩層が東 方へ流出し, 浦倉山火山体の活動が終息した.

\section{成層火山体の開析と関連する滝}

\section{1. “四阿カルデラ”の地質}

“四阿カルデラ”の成因として，爆発的な噴火(八木, 1941; 荒牧・早川, 1996 など) と崩壊イベント(西来ほか, 2014)が あげられているが，いずれの研究でも明瞭な根拠は述べられ ていない，そこで，その成因を検討するために，カルデラ内 およびその周辺の地形と地質の特徵を概観する. 太田・片田 （1955）によると, “四阿カルデラ”内の地質は, 不動堂溶岩, 米子凝灰角礫岩 (四阿火山の噴出物よりも古い火山岩類) およ び米子溶岩 (四阿火山の噴出物のうち最も古い)からなり, そ 


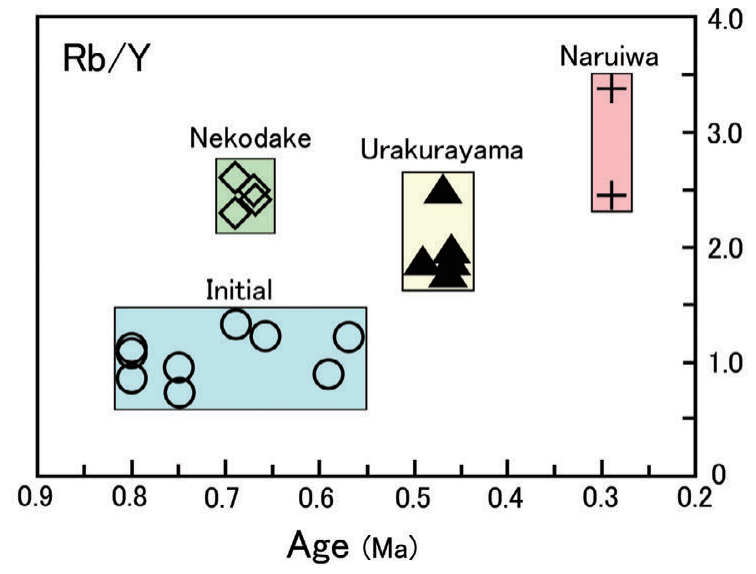

第 9 図. 四阿火山および鳴岩火山における $\mathrm{Rb} / \mathrm{Y}$ 比の時間変 化. 西来ほか (2014)の Fig. 8 に加筆修正.

Fig. 9. Temporal changes in the $\mathrm{Rb} / \mathrm{Y}$ ratios of rocks from Azumaya and Naruiwa volcanoes (modified from fig. 8 in Nishiki et al., 2014).

れらを米子奇妙溶岩, 浦倉溶岩, 四阿溶岩, 根子溶岩が取り 囲むように覆い，環状の山頂域を形成している。“四阿カル デラ”内の地質は, 権現沢と大黒沢に沿ってょく露出する. 以下，権現沢流域，大黒沢流域，米子鉱山跡～米子林道不動 線沿いの地域に区分して，それぞれの地域に露出する地質体 の概要を記述する. 露頭位置図を Fig. 10 に示す.

権現沢流域 : 権現滝の落ち口付近 (標高 $1,550 \mathrm{~m}$ ) から標高 $1,600 \mathrm{~m}$ 付近の権現沢河床には暗青灰色〜黒色の斑晶の目 立たない緻密な安山岩が断続的に露出する。この安山岩には 節理が発達し，それに沿って熱水変質を被っており，灰白色 ～黄白色を呈し粘土化している(Fig. 11a)。特に権現沢と登 山道が交差する標高 $1,580 \mathrm{~m}$ 付近の溶岩はいちじるしく変 質し，粘土化している. 以上の地質的特徴は, Locs. 1 4 で確認された。

権現沢の標高 $1,620 \mathrm{~m}$ 付近の左岸の崖には, 層厚 $2 \mathrm{~m}$ 程 度の薄い溶岩層を 2 枚挟む厚い凝灰角碟岩が露出する。凝 灰角碩岩には粒径の違いなどによる成層構造が見られる。こ の露頭の溶岩および凝灰角㗂岩は熱水変質を被っておらず, 新鮮な状態を保っている．溶岩層には開口性の亀裂が多数見 られる (Fig. 11b) ほか，凝灭角碩岩中の巨䃋にも開口性の亀 裂が認められるものが多い(Fig. 11c)，この堆積物は不動沢 と権現沢の間にある標高 $1,650 \sim 1,810 \mathrm{~m}$ にかけて広がる 緩やかな緩斜面を形成している. 以上の地質的特徵は, Loc. 5 で確認された.

権現沢標高 $1,655 \mathrm{~m}$ 付近の左岸の崖には凝灭角啋岩と層 厚 1 3 m ほどの薄い溶岩層との互層が露出する．溶岩層は 比較的新鮮な状態を保っているが，凝灰角碩岩部分を中心に 全体的に熱水変質作用を被って白色を呈し粘土化している. また，この露頭の凝灰角砂岩と溶岩層との互層は上流側に大 きく傾いている (Fig. 11d). 以上の地質的特徵は, Loc. 7 で確認された.

権現沢の標高 1,730 1,790 $\mathrm{m}$ 付近の河床および右岸の
崖には節理が発達する厚い溶岩層が断続的に露出する. 節理 に沿って 10〜100 cm 程度の幅で脈状に熱水変質作用を被つ て粘土化し, 白色〜灰白色を呈する. また標高 $1,740 \mathrm{~m}$ 付 近の右岸の崖では, 開口性の亀裂が発達する部分もある. 以 上の地質的特徵は, Locs. 10, 11 で確認された.

このほか Locs. 4，6，8，9 では，安山岩の巨砂を含む凝 灰角砅岩が露出し, それらは熱水変質作用を被って粘土化し 白色〜黄白色を呈することが確認された。 これらのうち， Loc. 6 の凝灰角砂岩に含まれる安山岩の巨砂には開口性の 亀裂が発達する。

大黒沢流域 : 大黒沢と権現沢を結ぶ登山道沿いの標高 $1,550 \mathrm{~m}$ 付近には, 板状節理の発達する暗青灰色〜黒色の 斑晶の目立たない緻密な安山岩が露出する。この安山岩は熱 水変質を被っておらず新鮮な状態を保っている. 大黒沢標高 $1,440 \mathrm{~m}$ 付近右岸の崖にも同溶岩が新鮮な状態で露出する. 以上の地質的特徵は, Locs. 12, 13 で確認された.

大黒沢の標高 1,500 1,600 m の大黒滝付近にかけて, 河床および両岸の崖に露出する地層はいちじるしく熱水変質 作用を被り，粘土化し白色を呈する (Fig. 11e). 米子鉱山の 坑口跡の周辺は特に変質が激しく, 侵食が進んでいる. 大黒 坑付近では変質しているものの弱い成層構造や砂の名残が認 められるため, 溶岩ではなく凝灰角碩岩が変質したものと思 われる. 以上の地質的特徵は, Locs. 14 18 で確認された. また, 大黒沢上流域右岸の標高 $1,600 \mathrm{~m} \sim 1,800 \mathrm{~m}$ 付近で は新鮮な地すべり地形が確認でき, その滑落崖には熱水変質 を被って白色化した部分が見られる(Fig. 11f).

米子硫黄鉱山跡から林道米子不動線沿い: 米子鉱山跡地およ び鉱山事務所跡地の東側には, 厚さ $50 \mathrm{~m}$ 以上の節理が発達 する暗青灰色〜黒色の緻密な安山岩が急峻な崖を形成してい る. 裏ノ沢にかかる奇妙滝付近にも同溶岩が新鮮な状態で露 出する.

裏ノ沢右岸側の林道米子不動沢線の標高 $1,440 \mathrm{~m}$ 付近に は暗青灰色〜灰色の安山岩が断続的に露出する. これらの安 山岩は節理に沿って脈状に変質している. 変質の脈の幅は数 $10 \mathrm{~cm} \sim 2 \mathrm{~m}$ 程度である. 以上の地質的特徵は, Locs. 20 〜22 で確認された. また, 裏ノ沢右岸側の林道米子不動沢 線の標高 1,420 m 付近 (Loc. 23) では, いちじるしく亀裂 が発達した安山岩の露頭が確認され, その背後には奇妙山平 と呼ばれる緩斜面がある.

\section{2. “四阿カルデラ”の成因と形成時期}

成層火山の山頂付近において直径数 $\mathrm{km}$ に達する凹地の 主な成因としては, 山体崩壊にともなう馬蹄形カルデラの形 成や大規模な爆発的噴火や地下のマグマの移動にともなう陥 没カルデラの形成のほか, 侵食作用による侵食カルデラの形 成があげられる.

西来ほか (2014) は, 記載岩石学的特徵に基づき“四阿カル デラ”内に分布する池の平溶岩が浦倉山火山体 (約 $50 \sim 45$ 万 年前)のグループに属すると考え, この火山体の活動をはさ んで少なくとも 2 回の崩壊イベントがあった可能性を指摘 した. 古い方の崩壊イベントでは浦倉山火山体の噴出物の分 布から北東側に，新しい方の崩壊イベントでは現在の米子川 


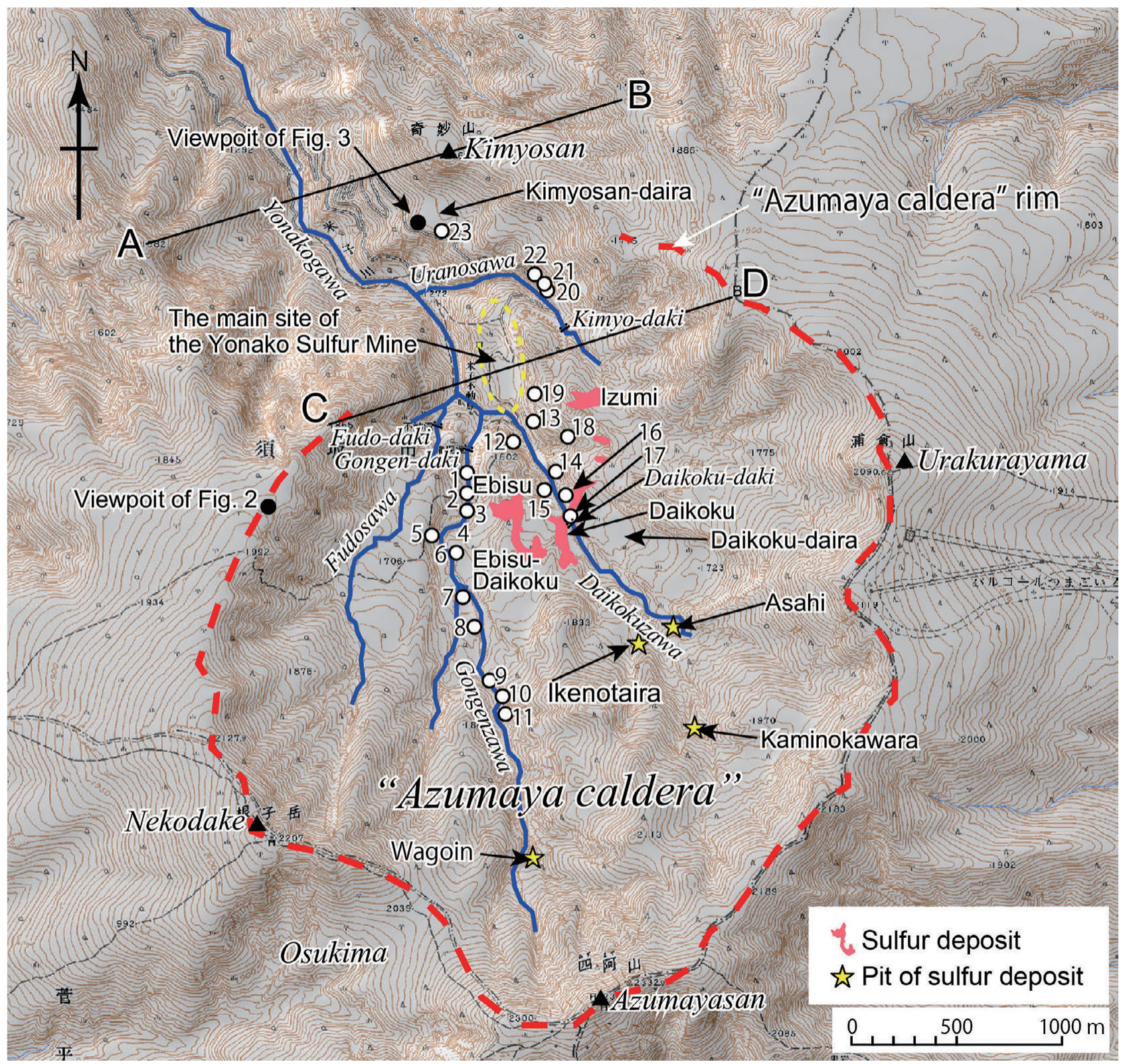

第 10 図. 米子硫黄鉱山の硫黄鉱床と坑道の配置および露頭位置図. 丸印は露頭位置を、ゴチックの数字は露頭番号をそれぞれ 示す．赤点線は“四阿カルデラ”の縁を示す。

Fig. 10. Distribution of sulfur deposits and pits at the Yonako sulfur mine, and locality map of the outcrops referred to. Open circles indicate the locations of outcrops, and each outcrop is numbered. The red dashed line shows the rim of "Azumaya caldera".

の流れ出る北西側に崩れたと推定した.“四阿カルデラ”が崩 壊イベントにともなって形成された地形であるならば, それ に対応する岩屑なだれ堆積物が山麓地域に分布するはずであ る.しかしながら，本間(1931) 以降，西来ほか(2014)の研 究まで, 四阿火山の地質を対象とした多くの研究を精査した が，岩屑なだれ堆積物に相当する記載は見当たらなかつた。 北東麓には浦倉山火山体の噴出物が広く分布するために，す ベて覆われている可能性もあり，古い方の崩壊イベントがな かったとは言い切れないが，北西側は新しい噴出物に覆われ ていない。また，約 30 万年前の鳴岩火山の噴出物が米子川
沿いに残存することから, 崩壊イベントに対応する堆積物が すべて侵食されてしまったとも考えにくい. また，磐梯火山 や雲仙火山の眉山など, 山体崩壊にともなう馬蹄形カルデラ の崩壊壁は, 崩壊した方向に開いた形状を呈することが多 い.これに対し, 現在の“四阿カルデラ”の縁は丸く閉じた形 状を呈する (Figs. 1，7，10)。これらのことを考え合わせれ ば，北東側へ崩れたとされる古い方の崩壊イベントについて は現段階では言及できないが，少なくとも北西側へ崩れる大 規模な崩壊イベントは存在しなかった可能性が高い.

また，西来ほか (2014)が指摘したように，四阿火山の火 

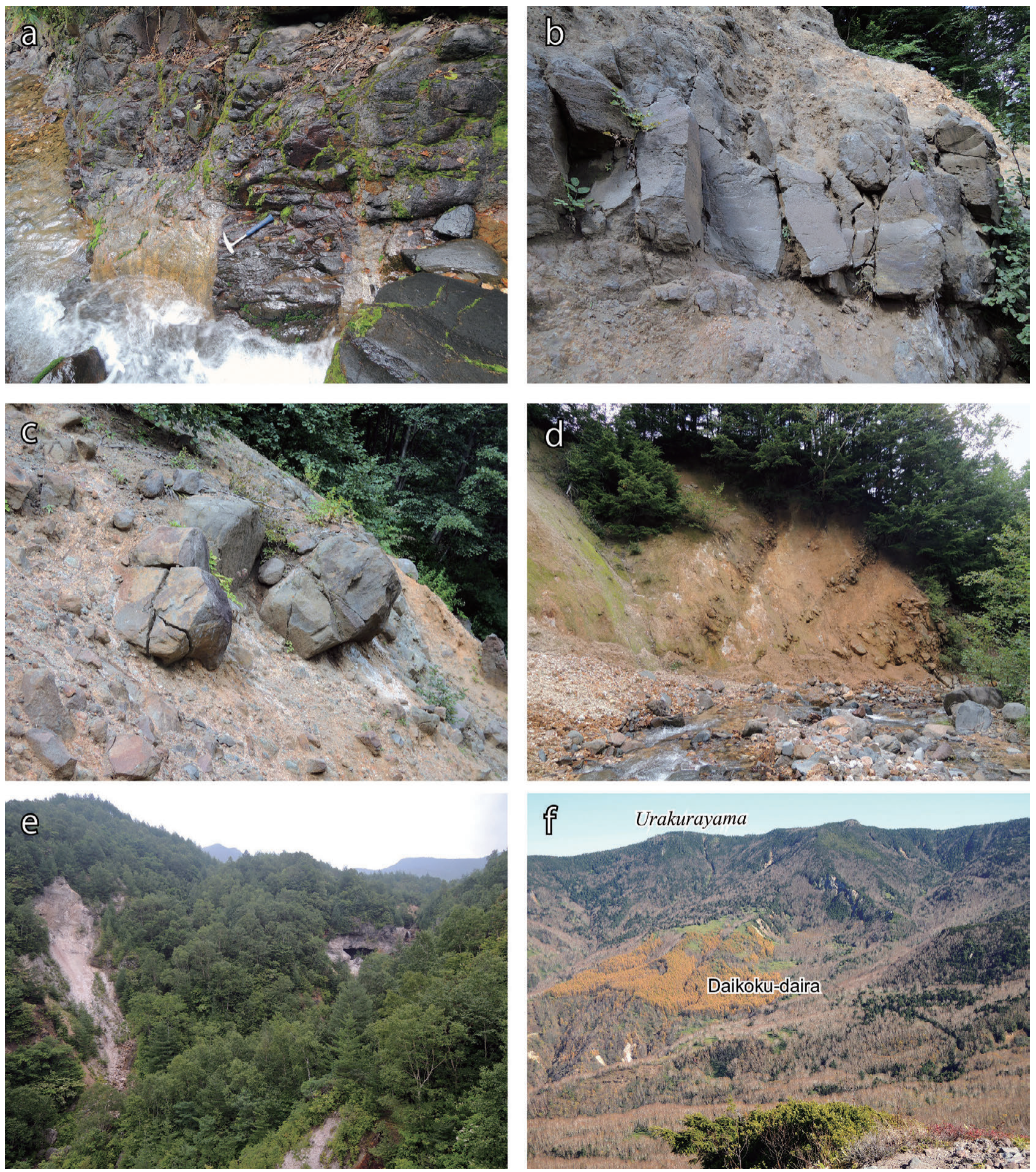

第 11 図. 四阿カルデラ内の代表的な露頭写真. 露頭位置は第 10 図に示す. a) 熱水変質を被つた米子溶岩層 (Loc. 2). b) 開口

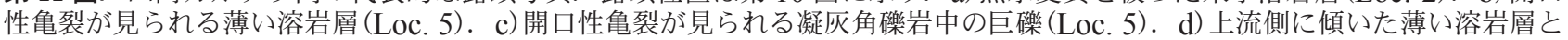
凝灰角砅岩層の互層 (Loc. 7)。e) 著しく熱水変質を被つた大黒沢沿いの地質体 (Locs. 15～17)。f) 大黒沢右岸に見られる新鮮な 地すべり地形 (大黒平).

Fig. 11. Photographs of representative outcrops in Azumaya caldera. The locations are shown in Fig. 10. a) Part of the Yonago Lavas altered by hydrothermal activity (Loc. 2). b) Thin lava with many open cracks (Loc. 5). c) Blocks (with many open cracks) in the tuff-breccia (Loc. 5). d) Alternated layers of thin lava and tuff breccia layer, which inclining to the upper stream (Loc. 7). e) Geological body along the Daikokusawsa that has been intensely affected by hydrothermal alteration (Locs. 15-17). f) Fresh landslide topography along the Daikokusawa right bank (Daikoku-daira). 
山体を構成する火山岩類は輝石安山岩，かんらん石輝石安山 岩および輝石デイサイトであり，Az-Mip のように普通角 閃石を多含するものはこれまで記載されていない(太田・片 田, 1955; 西来ほか, 2014)。さらに著者らによる地質踏査 でも角閃石を含む火山噴出物を“四阿カルデラ”周辺で見つけ ることはできなかった. Az-Mip の噴出にともない “四阿力 ルデラ”が形成された(荒牧・早川, 1996) とするには, 現状 では根拠がそしいと言わざるを得ない。

最後に侵食作用について検討する. 太田・片田(1955)が 明らかにしたように，権現沢，大黒沢沿いを中心に“四阿力 ルデラ”内の岩石は広く熱水変質作用を被って脆くなってい る(Fig. 11a, 11e)，特に大黒沢では変質がいちじるしいた めに他の沢よりも侵食が進み, 不動滝や権現滝などに比べ大 黒滝はかなり上流に位置する (Fig. 10)。権現沢では開口性 の亀裂が発達する溶岩および凝灰角㗂岩 (Fig. 11b, 11c), 層理面が上流側に大きく傾いた溶岩と凝灰角碟岩の互層を確 認することができる (Fig. 11d)。これらの権現沢沿いに露出 する地質体の特徵は，それらが地すべりによって移動したこ とを示唆している. さらに，大黒沢右岸の $1,600 \sim 1,850 \mathrm{~m}$ にかけて新鮮な地すべり地形が認められる(Fig. 11f)。この ような事実は, カルデラ内における侵食と地すべりの活動が 現在も活発であることを示している. また, 侵食カルデラで あると見なされている立山カルデラの崩壊壁は, “四阿カル デラ”の縁と同じように丸く閉じた形状を呈する(原山ほか， 2000; 中野ほか, 2010)，以上のことを考无合わせると，“四 阿カルデラ”は, 立山カルデラ同様に侵食カルデラと見なす ことが現段階では妥当であろう。しかしながら, 近年の研究 で三宅島の 2000 年噴火 (Geshi et al., 2002)やカトマイ火 山(アラスカ)の 1912 年噴火 (Fierstein and Wilson, 2005) など，地下のマグマの移動にともない陥没カルデラが形成さ れる事例が報告されている. 今回はその可能性について検討 していないため, “四阿カルデラ”がこの種の陥没カルデラで ある可能性は否定できない.

さて, “四阿カルデラ”はいつ形成された地形であろうか. 太田・片田(1955) は, 外輪山を構成する溶岩のうち, 浦倉 溶岩はカルデラ内に流入し, 米子熔岩を直接覆い, 硫黄鉱床 の近くでも鉱化作用を全く受けていないように観察されるの で, かなり新しいもの(更新世の後半)であるとした. 浦倉溶 岩からは $0.46 \pm 0.02 \mathrm{Ma}$ (金子ほか, 1989) と $0.46 \pm 0.01 \mathrm{Ma}$ (西来ほか, 2014)の $\mathrm{K}-\mathrm{Ar}$ 年代が報告されている. したがつ て太田・片田(1955) の指摘が正しいとするならば, “四阿力 ルデラ”の形成はこの溶岩の流出前, すなわち約 46 万年以 前ということになる。 これに対して西来ほか(2014) は, 初 期火山体, 根子岳火山体, 浦倉山火山体を構成する溶岩の分 布と年代值に基づき, 約 55 50 万年前と 45 万年前以降に 少なくとも 2 回の崩壊イベントが関与して“四阿カルデラ” (西来ほか (2014) では崩壊地形と表現している)が形成され たと推定した. このように“四阿カルデラ”の形成時期に関し ても見解は定まっていない.

米子川右岸の南東-北西方向に伸びる尾根上に米子奇妙溶 岩(太田・片田, 1955)が分布する (Figs. 7, 12)。この溶岩

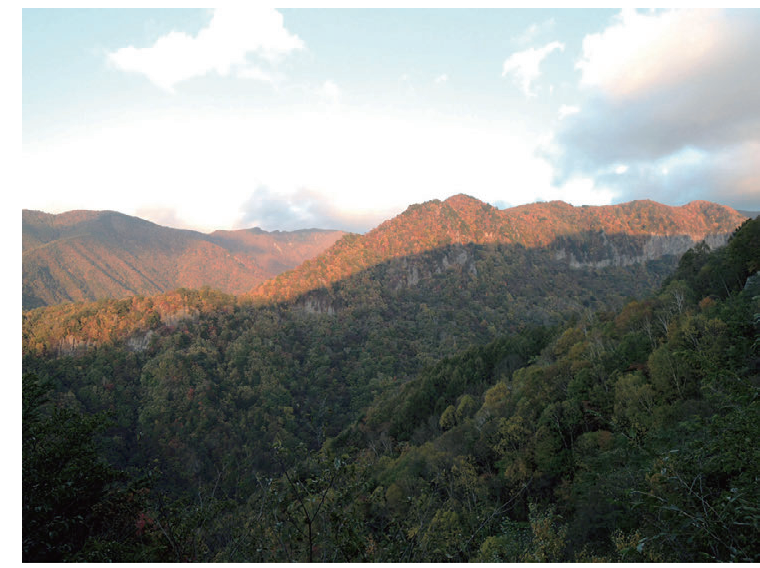

第 12 図. 米子奇妙溶岩層が構成する尾根.

Fig. 12. Ridge formed by the Yonagokimyo lavas.

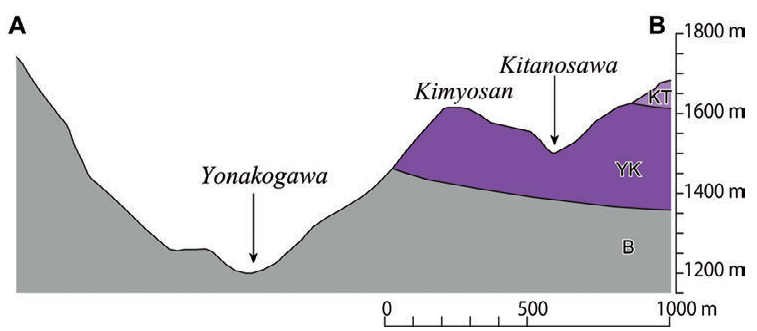

第 13 図. 米子川が形成する谷の地質断面概略図. 断面位置 は第 10 図の A-B. 略号 : KT, 上砥草溶岩層; YK, 米子 奇妙溶岩類 ; B, 基盤岩類.

Fig. 13. Schematic geological cross-section of the valley formed by the Yonakogawa. Cross-section along line A-B, shown on the map in Fig. 10. Abbreviations: KT, Kamitokusa lavas; YK, Yonakokimyo lavas; B, basement rocks.

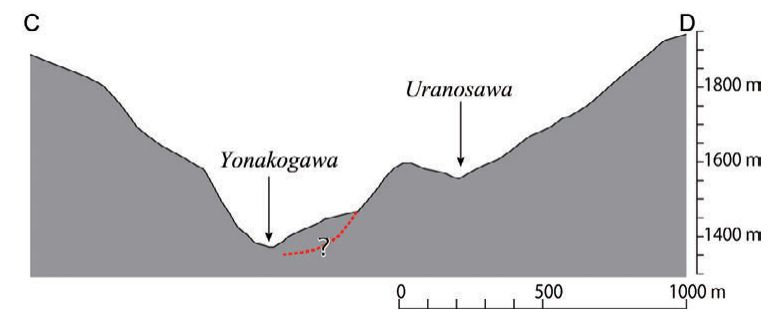

第 14 図. 米子硫黄鉱山付近の地すべり地形. 断面位置は第 10 図の C-D. 赤点線は推定される地すべり面を示す.

Fig. 14. Topographical cross-section of the landslide near the Yonako sulfur mine. Cross-section along line C-D, shown on the map in Fig. 10. The red dashed line indicates the inferred slip surface.

が噴出する以前の地形は, 尾根と谷の位置が現在とは逆で, 現在の米子川の部分が尾根, 米子奇妙溶岩が分布する尾根が 谷であったと考えられる. 米子奇妙溶岩からは, $0.46 \pm 0.01 \mathrm{Ma}$ の $\mathrm{K}-\mathrm{Ar}$ 年代值が得られている(西来ほか, 2014)。したがっ て, 現在の米子川は, 約 46 万年前以降に米子奇妙溶岩の西 側の縁に沿つて流れるようになったと考えられる。“四阿力 

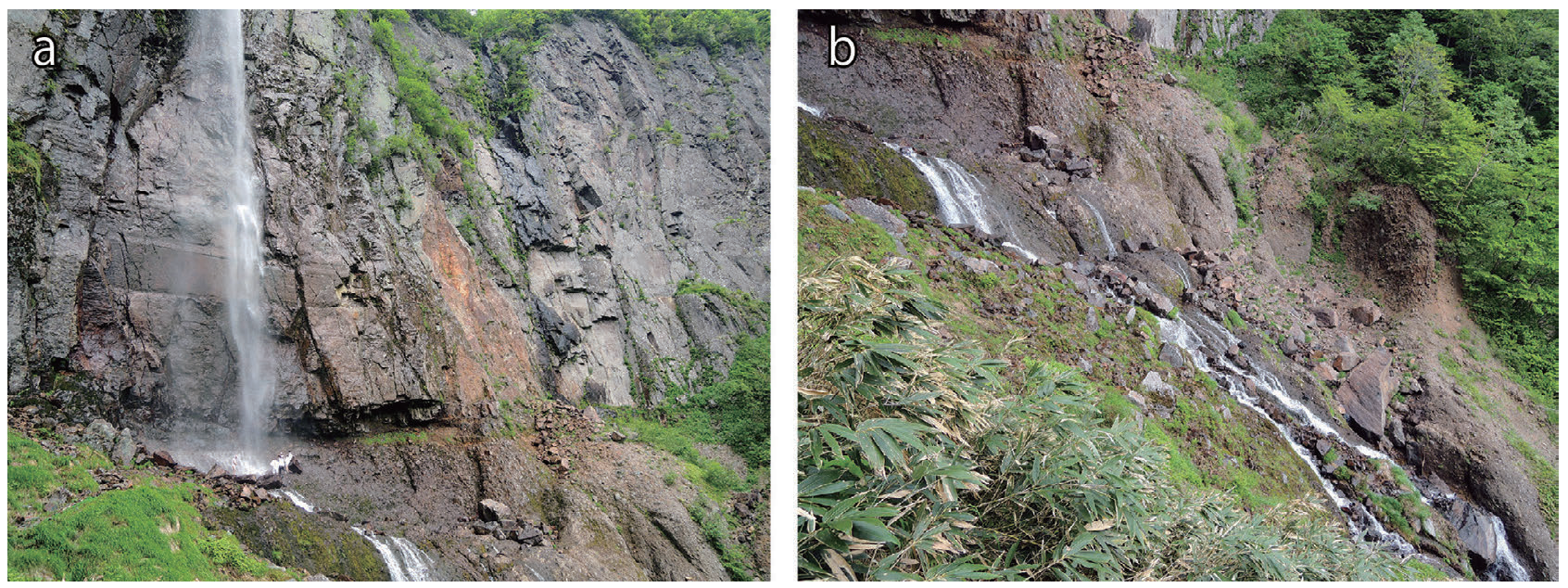

第 15 図. 不動滝での最近の米子溶岩層の崩落を示す証拠. a) 米子溶岩層基底部の侵食, b) 崩落した米子溶岩層の岩.

Fig. 15. Evidence for the recent breakage and collapse of the Yonago lavas at Fudo daki. a) Erosion of the basal part of the Yonago Lavas. b) Collapsed block of the Yonago Lavas.

ルデラ”から流れ出る河川は米子川のみであるから，北西側 に開く現在の“四阿カルデラ”は約 46 万年以降に形成されは じめた地形である可能性が高い。また米子川は，米子奇妙溶 岩がつくる地形面に比べ約 $400 \mathrm{~m}$ も低い位置を流れている (Fig. 13)。このことから，この川は約 46 万年間に $400 \mathrm{~m}$ 下刻したと考えられ，侵食力が非常に強いことを示してい る. 以上のことをまとめると, “四阿カルデラ”を形成した主 な要因は, 米子川の強い下方侵食による深い谷の形成と大規 模な熱水変質帯における地すべりの相互作用である可能性が 高く，その形成は約 46 万年前以降に始まり，現在でも活発 に続いていると考えられる.

地形の断面形態 (Fig. 14) や前縁部にいちじるしく亀裂が 発達した安山岩 (米子奇妙溶岩に相当)の露頭が見られること から, 米子硫黄鉱山跡地や奇妙山平といった米子川沿いの比 較的平坦な地形も地すべりによって形成されたものと考えら れる.こうした場所には，鉱山跡や遺跡があることから，人 は信仰や産業の場として自然の地形をうまく利用してきたこ とがうかがわれる。

\section{3. 米子の滝の成り立ち}

米子川上流部において, “四阿カルデラ”のほかに特筆され る地形として「米子の滝」がかかる約 $1 \mathrm{~km}$ にわたつて連続す る岩壁がある(Fig. 3)。八木(1941)は。この岩壁のほか, 主要なものでは四阿山と根子岳間の大鵪簡と呼ばれる鞍部 の岩壁, 大谷不動堂の周囲を取り巻く岩壁, 大谷不動東北部 の岩壁は爆裂火口の火口壁であると考えた. さらに, 太田・ 片田(1955)では山頂域を取り巻くように, 8 つの爆裂火口 を図示しており，その中に「米子の滝」のかかる岩壁も含まれ ている.これらの研究以降, 飯島・山岸(1964)や山岸 (1988)など多くの研究で八木 (1941) と太田・片田 (1955) の解釈が採用されており, 四阿山山頂域を取り巻く急峻な岩 壁は爆裂火口の火口壁であるという考えが浸透したようであ る.これに対して，小林ほか(2011)では，米子川は火口瀬
より上流で奇妙沢 (裹の沢) ・ 不動沢・権現沢・大黒沢と 4 河川に分岐するが, 下流側の比較的侵食に弱い新第三系の堆 積岩層に対して, ここで侵食に強い米子溶岩(太田・片田, 1955)の存在が侵食の復活を食い止めて遷急点を形成してい ると指摘しており, この地形が侵食作用によって形成された ものと推定している.

滝がかかる岩壁が爆裂火口の火口壁であるとすると, 爆裂 火口を形成した噴火は, 米子川の河床がほぼ現在の標高まで 下がってから，すなわちかなり新しい時代に起きたことにな る. そうでなければ, 前述のように米子川は強い侵食力を持 つために，爆裂火口は侵食により消失してしまうと考元られ る. しかし, 四阿火山の活動は, 多くの溶岩層の $\mathrm{K}-\mathrm{Ar}$ 年 代值から約 45 万年前で終了した可能性が高い(西来ほか, 2014). 仮に約 25 万年前の Az-Mip (町田・新井, 2003)が 四阿火山の噴出物であったとしても, それ以降この火山が活 動を継続した形跡は今のところ知られていない. 新しい時代 の活動であれば，それにともなう堆積物が確認できてよさそ うであるが，これまでの研究にも記載がない，以上のことか ら, 新しい時代に爆裂火口を形成する噴火があったとは考え にくく, 米子の滝が火口壁にかかる滝である可能性は低い.

爆裂火口の可能性が低く, 現在も米子川が活発に下刻して いることから, 小林ほか(2011)が推定したように, 現在見 られる米子の滝は侵食作用により形成された地形であり, 米 子溶岩最下部の厚い溶岩層 (不動滝溶岩 : 太田・片田, 1955) が侵食に対して強い抵抗力をもつために, 大規模な岩壁が形 成されたのであろう. 不動滝溶岩は柱状節理の発達する緻密 な安山岩で, 米子凝灰角啋岩を覆っている. 溶岩に比べ米子 凝灰角碩岩の方が侵食に弱いために, 現在の滝にも凝灰角礫 岩がえぐられて溶岩層がオーバーハングする様子が見られる (Fig. 15a)。小林ほか(2011)が指摘したように, この差別 侵食により滝の基部の侵食が進むと, やがて上部の溶岩が節 理に沿って崩落し, 滝は徐々に後退していくのであろう.こ 
れを裏付けるように，不動滝の下流側には過去に崩落した溶 岩の巨大な岩塊が見られる (Fig. 15b).

以上のことをまとめると，米子の滝の形成過程は次のよう になると考えられる. (1)約 46 万年前に古い谷地形を米子奇 妙溶岩が流下し埋め立てる. (2)この溶岩の西側の縁に沿つて 侵食がはじまり, 米子川ができはじめ, 旺盛な侵食力により 下刻が進む。 (3)侵食が不動滝溶岩まで達し, 滝の形成がはじ まる. (4)差別侵食による溶岩の崩落により現在の位置まで滝 が後退し, 現在見られるような不動滝, 権現滝がかかる巨大 な岩壁が形成された.

\section{米子硫黄鉱山と坑排水}

\section{1. 米子硫黄鉱山の概略}

米子硫黄鉱山の歴史と地質については，太田・片田(1955) と齋藤 (2012) に詳しくまとめられている. ここでは, この 2 つの研究に基づき米子硫黄鉱山の概略を紹介する.

米子硫黄鉱山の主要な鉱床は, 大黒滝周辺を中心として権 現沢と裏ノ沢にはさまれた東西 $600 \mathrm{~m}$, 南北 $1,000 \mathrm{~m}$ の地 域に分布し(Fig. 10), 不動滝溶岩 (米子溶岩の最下部を構成 する厚い溶岩層：太田・片田, 1955)の最上部付近のほぼ同 一層準に賦存する. エビス，エビス大黒，大黒，泉などの主 要な鉱床のほかに, “四阿カルデラ”内には旭坑, 池ノ平坑, 上ノ河原坑，和合院坑の鉱床がある. 鉱体の主要部は, 熱水 変質作用により蛋白石化した緻密もしくは多孔質の安山岩中 に鉱染状に遊離硫黄が交代したものであり，鉱体内の品位分 布は不規則である。鉱体主要部の外縁部には「鷹ノ眘」と呼ば れる硫黄結晶の大きな塊(3〜200 cm) が斑状に含まれてい る.

米子硫黄鉱山の採掘の歴史は，古く寛永年間 (1624-1643 年)の硫黄山稼ぎに関する資料にさかのぼる．近江の治兵衛 という人物がはじめて硫黄の採掘を請負つて以来, 幕末ま で潼頭・大望・沢場・泉・和合院・怠美須および屋源苗の 7 地区で稼業されたようであるが，いずれも小規模で断続的 であったらしい. 明治以降は企業組織の鉱山会社によって近 代化された採鉱法や精錬法が取り入れられ，大規模に稼行さ れた．数代の経営者を経て，1936(昭和 11) 年に中外鉱業株 式会社による稼行がはじまり, 経営は安定し生産量が飛躍的 に増した. 最盛期の 1937 (昭和 12)～1942 (昭和 17) 年にか けては, 年間の硫黄生産量が 1 万 $\mathrm{t}$ を超えていた. その後, 1944 (昭和 19) 年から戦時下の硫黄鉱山の企業整備のため帝 国鉱業株式会社に譲渡されるも，1950（昭和 25）年に再び中 外鉱業株式会社により稼業されることになる。しかし，原油 の精製工程で回収される硫黄に押され，1960（昭和 35) 年に 採掘を打ち切り, 硫黄鉱山は閉山した.

\section{2. 廃坑から流出する酸性水}

四阿火山の西麓, 長野盆地東部に位置する須坂・上高井 地域(須高地区)では，河東山地から千曲川に流入する複数 の水系の酸性水対策が課題になっている. 須高地区はいわゆ る「酸川」架中域で，米子川とその下流の百々川，松川など の河川水は強い酸性 (pH 3 4) を示す (河野ほか, 1986). 酸 性河川が生じる基本的な原因は，上流域に豊富に存在する硫

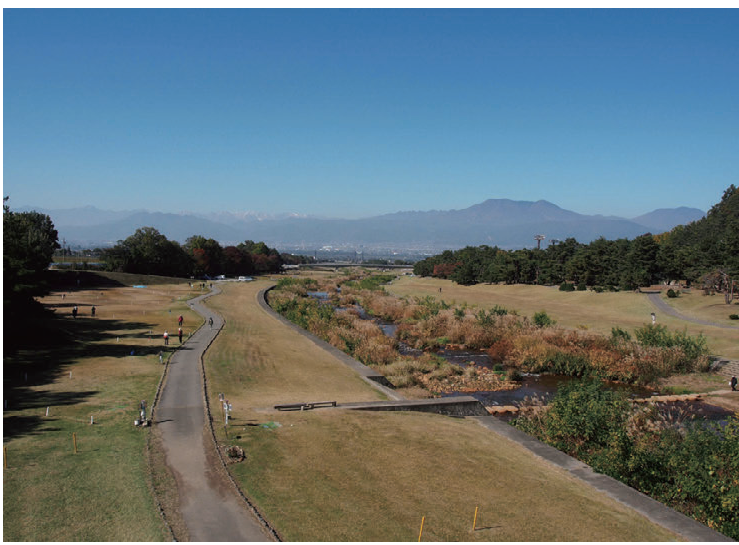

第 16 図. 須坂市臥竜 (Stop 1) から望む長野盆地 (善光寺平) と西山(水内丘陵)

Fig. 16. Photograph of the Nagano Basin (Zenkoji Daira) and Nishiyama Mountains (Minochi Hills), viewed from Garyu, Suzaka City (Stop 1).

化物が大気に触れて酸化され, 水による溶解とともに多量の 硫酸イオンが河川に流出するためと考えられる. その際, 硫 黄と結合していた金属イオンも水に溶解することから, 酸性 河川水は重金属を含む有害な水質となる.したがってこのよ うな酸性河川には魚類が生息せず，下流域における水利用は 大きく制限され，農業被害や健康被害をもたらすことにもな る. 星加ほか (1984)によれば, 須高地区の酸性河川水中の 硫酸イオンの濃度は最高 $160 \mathrm{ppm}$ で，わが国の河川水中の 硫酸イオン濃度の平均值 $10.9 \mathrm{ppm}$ の約 16 倍に達する. ま た酸性河川となった要因には, もともとの地質に由来する自 然的要因と, かつて硫黄等を採掘した休廃止鉱山の抗廃水に 由来する人為的要因の両方がある. 米子川水系の 50 地点に ついておこなつた水質調査結果をもとに，河野ほか (1990) が主たる負荷源について検討した結果では, 人為要因に起因 する $\mathrm{SO}_{4}{ }^{2-}$ の負荷割合が 6 割前後と試算されるとともに, 自 然要因と人為要因との影響割合は支流の沢ごとにも異なると している.

須高地区の主な休廃止鉱山としては, 百々川水系の米子川 上流にある米子鉱山のほか, 松川上流の横手山鉱山，松川水 系の樋沢川上流の小串鉱山などがある. 長野県はこれらの休 廃止鉱山対策として, 昭和 57 年度から平成 8 年にかけて小 串鉱山跡地, 米子鉱山跡地および横手鉱山跡地の覆土, 排水 および緑化工事等を実施している. しかし, 昭和 59 年から 29 年間にわたり須高地区の松川および百々川水系の 5 地点 で継続して行われている水質調査の結果では, 酸性河川の水 質変動の傾向にほとんど変化がなく, 河川水が $\mathrm{pH} 5$ 前後な いし 4 以下の值を示す状況は改善していない(長野県環境保 全研究所, 2013).

\section{見 学 地 点}

Stop 1 須坂市野辺臥竜橋(百々川) : 四阿火山周辺の地形 地質

[地形図] $1: 25,000$ 「須坂」 
[位置 $] 36^{\circ} 38^{\prime} 18^{\prime \prime} \mathrm{N}, 138^{\circ} 18^{\prime} 59^{\prime \prime} \mathrm{E}$

[解 説] 見学地点は百々川下流の後期更新世の扇状地上に位 置しており, 橋の上から長野盆地と西山 (水内丘陵) を眺望す ることができる (Fig. 16)。長野盆地周辺の大きな地形の特 徵を観察するとともに, 盆地をはさんだ東西の山地の特徽の 違いやそれぞれの成り立ちなどについて概略を説明する。

\section{Stop 2 不動滝 : 米子溶岩と米子凝灰角碟岩}

[地形図] $1: 25,000$ 「四阿山」

[位 置] $36^{\circ} 34^{\prime} 5^{\prime \prime} \mathrm{N}, 138^{\circ} 24^{\prime} 16^{\prime \prime} \mathrm{E}$

[解 説] 不動滝では, 四阿火山の最初期の噴出物である米子 溶岩とその下位の米子凝灰角磎岩を観察する.

米子溶岩 (太田・片田, 1955) は, 主に“四阿カルデラ”内に 分布する溶岩とそれに伴う同質の火砕岩である. 見学地点で は柱状節理の発達した層厚 $50 \mathrm{~m}$ 以上の溶岩がみられ，基盤 岩類の米子凝灰角礫岩を直接覆う。太田・片田(1955) はこ の厚い溶岩を不動滝溶岩と呼び，それより上位の部分と区分 している，岩質は単斜輝石含有斜方輝石デイサイトで，本溶 岩層から $0.75 \pm 0.05 \mathrm{Ma}$ (内海ほか, 1998), $0.77 \pm 0.04 \mathrm{Ma}$ （西来ほか, 2014）という $\mathrm{K}-\mathrm{Ar}$ 年代が報告されている.

\section{Stop 3 不動寺裏の登山道 : 権現滝の遠望}

[地形図] $1: 25,000$ 「四阿山」

[位 置] $36^{\circ} 34^{\prime} 5^{\prime \prime} \mathrm{N}, 138^{\circ} 24^{\prime} 21^{\prime \prime} \mathrm{E}$

[解 説] 展望台より落差約 $75 \mathrm{~m}$ の権現滝を遠望する.この 滝も不動滝と同一の溶岩にかかっている. 初夏には新緑と, 秋には紅葉とともに美しく彩られた滝を眺めることができ る. 権現滝より上流では，熱水変質作用を被って白く粘土化 した米子溶岩が露出する。この地点から下り，登山道が権現 沢を横切る地点では, 成層構造の見られる米子凝灰角砅岩層 を観察することができる.

\section{Stop 4 大黒沢・権現沢間の登山道 : “四阿カルデラ”と地 すべり地形}

[地形図] $1: 25,000$ 「四阿山」

[位 置] $36^{\circ} 34^{\prime} 2^{\prime \prime} \mathrm{N}, 138^{\circ} 24^{\prime} 26^{\prime \prime} \mathrm{E}$

[解説]浦倉山，四阿山などを含む環状の山稜に囲まれた “四阿カルデラ”の地形および大黒沢右岸の地すべり地形を観 察する．大黒沢右岸の地すべり地形は，高さ約 $100 \mathrm{~m}$ ，幅 約 $300 \mathrm{~m}$ の滑落崖とその下に広がる平坦な地形で構成され る. 滑落崖には点々と熱水変質により白色化した部分が見ら れる. この平坦な地形は, 米子硫黄鉱山時代には大黒平と呼 ばれ，褐鉄鉱の採取場のほか社宅や火薬庫があった(齋藤, 2012).落葉した晚秋には，この地点から大黒坑道の入り口 も眺めることができる. 米子硫黄鉱山として開発された一帯 は植林され，現在はカラマツ林になっている.

\section{Stop 5 権現沢 : 熱水変質帯と廃坑跡から流出する酸性水} [地形図] $1: 25,000$ 「四阿山」

[位 置] $36^{\circ} 33^{\prime} 56^{\prime \prime} \mathrm{N}, 138^{\circ} 24^{\prime} 22^{\prime \prime} \mathrm{E}$

[解＼cjkstart説]根子岳に向かう登山道が，権現滝の上で権現沢を渡

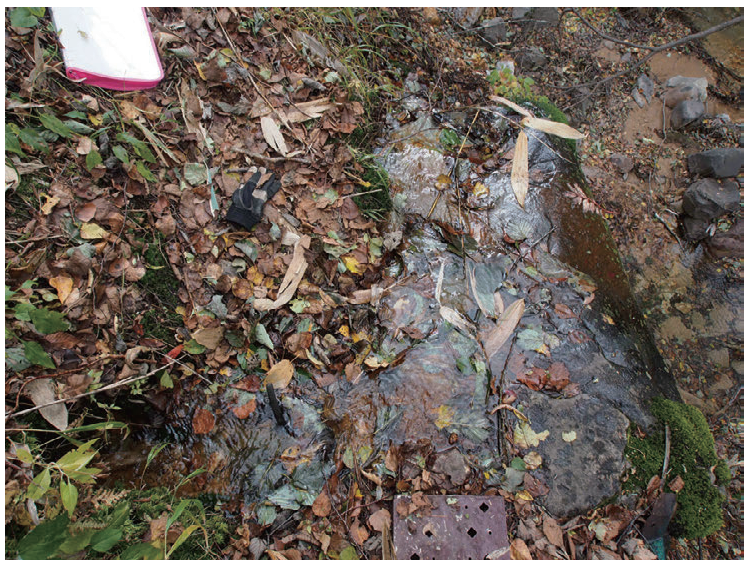

第 17 図. Loc. 3 における湧水の写真. 露頭位置は第 10 図 に示す.

Fig. 17. Photograph of spring water at Loc. 3. The location is shown in Fig. 10.

第 1 表. 権現沢上流 $1590 \mathrm{~m}$ 右岸 (Loc. 3) における湧水の水 質検査結果.

Table 1. Results of an analysis of the spring water on the Gongensawa right bank, $1590 \mathrm{~m}$ above sea level (Loc. 3, shown in Fig. 10).

\begin{tabular}{ccc}
$\mathrm{pH}$ & $\begin{array}{c}\mathrm{EC} \\
(\mathrm{mS} / \mathrm{m})\end{array}$ & instrument \\
\hline 3.0 & 70.0 & $\begin{array}{c}\text { portable EC } / \mathrm{pH} \\
\text { meter (WM-32EP) }\end{array}$ \\
\hline
\end{tabular}

る地点である (Loc. 3). 河床部の熱水変質を受けた火山岩 の露頭と, 廃鉱山の痕跡を観察する.ここでは, 毎分数十 リットル規模の湧水があり, それが沢に流入している様子が 観察できる (Fig. 17). 周辺の状況とその流出形態から, お そらくはかつての鉱山の坑道内からの排水跡と考えられる. 2014 年 10 月 17 日に調査した際には, 湧水は無色透明で, 水温は $8.3^{\circ} \mathrm{C}$ であった。 また, 流路沿いには酸性水に耐性 をもつと思われる緑色の苔類の繁殖もみられた. この湧水を 採水し, 室内で行った水質検査結果では, pH 3.0 の值が得 られた(Table 1).

\section{Stop 6 米子鉱山精錬所跡：硫黄鉱床と米子大瀑布遠望} [地形図] $1: 25,000$ 「四阿山」

[位 置 $] 36^{\circ} 34^{\prime} 16^{\prime \prime} \mathrm{N}, 138^{\circ} 24^{\prime} 23^{\prime \prime} \mathrm{E}$

[解 説] 米子大瀑布もしくは米子の滝と呼ばれる不動滝と権 現滝を一望することができる. また，その反対側の岩壁には 泉坑と呼ばれた硫黄鉱床が見られ, そこから崩落した硫黄鉱 石の転石も観察することができる. 岩壁を構成する厚い溶岩 （不動滝溶岩：太田・片田, 1955) では節理に沿つて幅数 m ほどの部分が白色に変質しているの夕であるが，それを覆う 凝死角碩岩層は広い範囲が白色に変質している. 鉱山の最盛 期である 1941 (昭和 16 年) ごろには精錬用焼取炉 28 基の 煙突が林立していた(齋藤, 2012). 米子硫黄鉱山跡および不 
動滝，権現滝の一帯は，滝や植生といつた美しい自然景観だ けでなく山岳修験の場としての景観も備えており, 良好な風 致の維持を図る必要性の高い地区であるとみなされ，2010 年に上信越高原国立公園の第 2 種特別地域に指定された.

\section{Stop 7 米子硫黄鉱元山事務所跡 : 四阿カルデラと米子溶岩} [地形図] $1: 25,000$ 「四阿山」

\section{[位 置] $36^{\circ} 34^{\prime} 22^{\prime \prime} \mathrm{N}, 138^{\circ} 24^{\prime} 24^{\prime \prime} \mathrm{E}$}

[解 説] “四阿カルデラ”や不動滰溶岩のつくる岩壁といつた 成層火山体の開析によって生み出された壮大な自然景観だけ でなく, 精錬所跡や大黒沢といつた米子硫黄鉱山跡を一望す ることができる.この場所には鉱業所の所長や採鉱課長をは じめとする会社の幹部や労務係や庶務係などが常駐する鉱山 事務所があった，そのほかにも仁礼小学校・米子分教場や青 年学校, 診療所, 合宿所, 映画館などの施設が設けられてい た(齋藤, 2012).

\section{謝 辞}

権現沢に流入する湧水の水質については, 長野県環境保全 研究所の小澤秀明氏に水質検査をしていただき, 関連する文 献を紹介していただいた. 査読者の富山大学の石㟝泰男准教 授ならびに産業技術総合研究所の石塚吉浩博士，担当編集委 員の大藤 茂教授のご指摘とご助言により内容が大きく改善 された. 以上の方々に心より感謝申し上げます。

\section{文献}

赤羽貞幸・竹下欣宏 (Akahane, S. and Takeshita, Y.), 2011, 第 2 章 大地のなりたち一地質一. 須坂市誌 第 1 巻 自然編 (The History of Suzaka City, Vol.1 Natural History), 89-152.

荒牧重雄・早川由紀夫 (Aramaki, S. and Hayakawa, Y.), 1996, 四 阿火山, 新版 地学事典 (Cyclopedia of Earth Sciences), 平凡社 (Heibonsha Ltd.), 22.

Fierstein, J., and Wilson, 2005, Assembling an ignimbrite: Compositionally defined eruptive packages in the 1912 Valley of Ten Thousand Smokes, Alaska. Geol. Soc. Amer. Bull. 117, 1094-1107.

Geshi N., Shimano T., Chiba T., Nakada S., 2002, Caldera collapse during the 2000 eruption of Miyakejima volcano, Japan. Bull. Volcanol., 64, 55-68.

原山 智・高橋 浩・ 中野 俊・荻谷愛彦・駒澤正夫 (Harayama, S., Takahashi, Y., Nakano, S., Kariya, Y. and Komazawa, M.), 2000 , 立山地域の地質. 地域地質研究報告 (5 万分の 1 地質図幅) (Geology of the Tateyama District. With Geological Sheet Map at 1: 50,000), 地質調査所 (Geol. Surv. Japan), 218p.

早津賢二(Hayatsu, K.), 2008, 妙高火山群一多世代火山のライフヒ ストリーー。 (Myoko Volcanoes), 実業広報社 (Jitsugyo-koho Co., Ltd.), 421p.

星加安之・小山 裕・奥山周作・五味一エリーザーエリカ・村山忍三 (Hoshika, Y. Koyama, Y. Okuyama, S. Gomi, E, E. and Murayama, N.), 1984, 硫黄廃鉱下流における水資源の保全と 健康の保護に関する研究(第一報) 一長野県須高地方における硫 黄廃鉱からの酸性河川水中金属イオンおよび陰イオンの分析一. 信州大学環境科学論集(Bull. Eviron. Conserv., Shinshu Univ. , no. 6, 51-55.

本間不二男(Honma, F.), 1931, 中部信濃地質誌 (Geology of the Central Part of Shinano)*. 信濃教育会小県上田部会 (Chiisagata Ueda Subcommittee, Shinano Education. Board)*, $191 \mathrm{p}$.

飯島南海夫 ・ 山岸猪久馬 (Iijima, N. and Yamagishi, I.), 1963, 四
阿火山群, 上田小県誌 第四巻 自然編 (The History of Magazine of Ueda-Chiisagata Region), 179-181.

金子隆之 - 清水 智・板谷徹丸 (Kaneko, T. Shimizu, S. and Itaya, T.) $, 1989, \mathrm{~K}-\mathrm{Ar}$ 年代からみた信越高原地域の火山活動. 岩鉱 (Jour. Mineral. Petrol. Econ. Geol.), 84, 211-225.

加藤碵一 - 赤羽貞幸 (Kato, H. and Akahane, S), 1986, 長野地域の 地質. 地域地質研究報告 (5 万分の 1 地質図幅) (Geology of the Nagano District. With Geological Sheet Map at 1: 50,000), 地質調査所 (Geol. Surv. Japan), 120p.

Kioka, H., Furuyama, K., Miyake, Y., Sakai, J., Nagao, K., Ikemoto, M., Noiri, H. and Oda, K., 1998, K-Ar chronology of the Middle Pleistocene lavas at Ontake volcano, central Japan. Earth Sci. (Chikyu Kagaku), 52, 464-474.

河野行雄・関久人 - 宮島勲 (Kono, Y. Seki, H. and Miyajima, I.), 1986, 須高地方酸性河川の水質特性. 長野県衛生公害研究所研 究報告(Bull. Nagano Res. Inst. Health Pollut.), 9, 11-17.

河野行雄 - 原田 勉 - 村松紘一 - 樋口澄男 - 近藤君夫 - 桑原秀明 (Kohno, Y. Harada, T. Muramatsu, K. Higuchi, S. Kondo, K., and Kuwabara, H.), 1990, 米子川水系の水質特性. 長野県 衛生公害研究所研究報告 (Bull. Nagano Res. Inst. Health Pollut.), 13, 7-12.

小林 詢 - 渡辺敏泰 - 廣内大助 (Kobayashi, M. Watanabe, T. Hirouchi, D.), 2011, 第 1 章 小るさとの生活舞台一地形一. 須坂市 誌 第 1 巻 自然編 (The History of Suzaka City, Vol.1 Natural History), 49-88.

町田 洋・新井房夫 (Machida, H. and Arai, H.), 2003, 新編火山灰 アトラス (Atlas of Tephra in and around Japan). 東京大学出 版会 (Univ. Tokyo Press), 336p.

松本盆地団体研究グループ (Matsumoto Basin Collaborative Research Group), 2002, 古期御岳火山の地質. 地球科学 (Earth Sci. (Chikyu Kagaku)), 56, 65-85.

宮澤慶男 (Miyazawa, Y.), 2014, 第 I 編 旧市町村別の地区史 第八 章 仁礼地区. 須坂市誌 第 2 巻 地史・民俗編 (The History of Suzaka City, Vol.2 Geohistory and Folklore), 259-290.

中野 俊 - 竹内圭史 - 加藤碵一 - 酒井 彰 - 浜崎聡志 - 広島俊男 - 駒沢 正夫(Nakano, S., Takeuchi, K., Kato, S., Sakai, A., Hamasaki, S., Hiroshima, T. and Komazawa, M.), 1998, 20 万分の 1 地質図幅「長野」(Geological Map of Japan 1: 200,000, Nagano). 地質調查所 (Geol. Surv. Japan).

中野 俊 - 奥野充・菊川茂 (Nakano, S., Okuno M. and Kikukawa S.), 2010, 立山火山. 日本地質学会第 117 年学術大会旅行見学 旅行案内書 (Excursion Guidebook 117th Ann. Meet. Geol. Soc. Japan), 地質雑 (Jour. Geol. Soc. Japan), 116, 補遺 (Supplement), 37-48.

中野 俊・西来邦章 - 宝田晋治 - 星住英夫 · 石塚吉浩 - 伊藤順一 一川 邊禎久 - 及川輝樹 - 古川竜太 ・ 下司信夫 - 石塚 治 - 山元孝広 岸本清行 (Nakano, S., Nishiki, K., Takarada, S., Hoshizumi, H., Ishizuka, Y., Itoh, J., Kawanabe, S., Oikawa, T., Furukawa, R., Geshi, N., Ishizuka, O., Yamamoto, T. and Kisimoto, K.), 2013, 日本の火山(第 3 版). 200 万分の 1 地質編集図 (1: 2,000,000 MAP SERIES, Volcanoes of Japan (Third Edition)), No.11, 地質調査総合センター(Geol. Surv. Japan, AIST).

長野県環境保全研究所 (Nagano Nature Conservation Research Institute), 2013, 2 須高地区酸性水対策調查. 長野県環境保全研 究所業務年報 $(A n n . R e p . N E C R I), 9,7$.

長森英明・古川竜太 - 早津賢二 (Nagamori, H., Furukawa, R. and Hayatsu, K.), 2003, 戸隠地域の地質. 地域地質研究報告 (5 万 分の 1 地質図幅) (Geology of the Togakushi District. With Geological Sheet Map at 1: 50,000), 産総研地質調査総合セ ンター(Geol. Surv. Japan, AIST), 109p.

西来邦章 - 竹下欣宏 - 田辺智隆 - 松本哲一(Nishiki, K., Takeshita, Y, Tanabe, T. and Matsumoto, A.), 2014, 中部日本, 四阿火山 の $\mathrm{K}-\mathrm{Ar}$ 年代 : 四阿火山の火山活動史の再検討. 地質雑 (Jour. Geol. Soc. Japan), 120, 89-103.

大石雅之 (Oishi, M.), 2009, 四阿火山を起源とする噴出物の岩石記 載的特徴とテフラ分布. 地学雑 (Jour. Tokyo Soc. Geogr.), 118, 1237-1246. 
太田良平・片田正人 (Ota, R. and Katada, M.), 1955, 5 万分の 1 地 質図幅「須坂」及び同説明書 (Geology of the Suzaka District. With Geological Sheet Map at 1: 50,000), 地質調査所 (Geol. Surv. Japan), 75p.

齋藤保人(Saito, Y.), 2012, 米子硫黄鉱山史(History of Yonako Sulfur Mine)。筑北炭田 (西条炭) 採掘史研究会 (Chikuhoku Tanden (Nishijotan) Saikutsushi Kenkyukai), 258p.

塩野入忠雄 (Shionoiri, T.) , 1983, 菅平高原地方の地質一四阿火山・ 烏帽子火山群 (Geology of the Sugadaira Highland: Azumaya Volcano and Eboshi Volcano Group)*. 銀河書房(Ginga Shobo), 127p.

鈴木毅彦(Suzuki, T.), 2000, 飛騨山脈貝塩給源火道起源の貝塩上宝 テフラを用いた中期更新世前半の地形面編年. 地理評 (Geogr. Rev. Japan), 73, 1-25.

鈴木毅彦・早川由紀夫(Suzuki, T. and Hayakawa, Y.), 1990, 中期 更新世に噴出した大町 Apm テフラ群の層位と年代. 第四紀研究 (Quatern. Res.), 29, 105-120.

田辺智隆・上信火山団体研究グループ(Tanabe, T. and Collaborative Research Group for Jo-Shin Volcanic Terrain), 1992, 菅 平から嬬恋高原にかけて分布する中部更新統. 第四紀 (Quatern. (Daiyonki)), no. 25, 47-56.

嬬恋村誌編集委員会編 (Tsumagoi Ed.), 1977, 嬬恋村誌 上巻 (The History of Tsumagoi Village, vol.1)，嬬恋村誌編集委員会 (Tsumagoi Ed.), 1154p.

内海茂・中野 俊- 宇都浩三 (Uchiumi, S., Nakano, S. and Uto, K.), 1998, 20 万分の 1 地質図幅「長野」地域の年代未詳岩石の $\mathrm{K}-\mathrm{Ar}$ 年代. 地調月報 (Bull. Geol. Surv. Japan), 49, 189-193. 八木貞助(Yagi, T.), 1941, 上高井地質誌 (Regional Geology of Kamitakai). 上高井教育会(Kamitakai Education Board)*, 230p.

矢口裕之 - 田辺智隆 (Yaguchi, H. and Tanabe, T.), 1990, 群馬県北 部に分布する中期更新世の火山灰層. 日本第四紀学会講演要旨 集 (Quatern. Soc. Japan, Abstr.), 20, 120-121.

山岸猪久馬(Yamagishi, I.), 1988, 第 5 章 火山 5.4 那須火山体南 端部の火山 (2) 四阿火山, 日本の地質 4 中部地方 I Regional Geology of Japan, Part 4 Chubu I)，共立出版(Kyoritsu Shuppan), 204.

[URL1] 新版長野県地質図作成委員会編 (Editorial Committee of New Geological Map of Nagano Prefecture), 2010, 新版長 野県地質図 ver.1. http://www.pref.nagano.lg.jp/kanken/chosa/ kenkyu/chishitsu/chishitsuzu.html

*English translation from the original written in Japanese

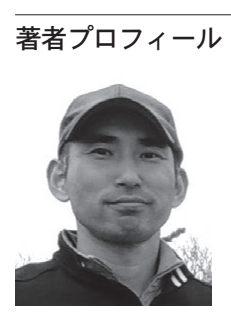

竹下欣宏 信州大学学術研究院教育学系准教授. 99 年 信州大学理学部卒, 04 年 信州大学大学院工 学系研究科博士後期課程修了 (理学博士), 04 年 栃木県立博物館学芸嘱託員, 08 年 戸隠地質化石 博物館専門員, 10 年 信州大学教育学部助教, 12 年から現職. 研究内容: 火山灰層序に基づく地形・ 地質発達史の解明. 本研究では, 現地調査・総括・ 原稿執筆・編集委員会との対応を担当. E-mail： takey@shinshu-u.ac.jp

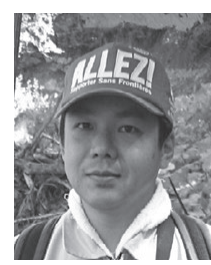

西来邦章 原子力規制委員会原子力規制庁技術研 究調査官. 01 年 信州大学理学部卒, 07 年 信州 大学大学院工学系研究科博士後期課程修了博士 (理学), 08 年 産業技術総合研究所特別研究員, 13 年 産業技術総合研究所テーマ型任期付研究員, 15 年から現職. 研究内容: 火山活動変遷史からみ た新生代の地質構造発達史の解明. 本研究では, 現地調査・原稿執筆 (四阿火山の活動史) を担当. E-mail : kuniaki_nishiki@nsr.go.jp

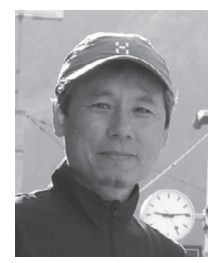

富樫 均 長野県環境保全研究所自然環境部専門 研究員. 信州大学理学部卒, 85 年 同大学院修了 (地質学専攻, 理学修士), 建設コンサルタントを 経て 96 年長野県自然保護研究所 (現職の前身)に 入所，技術士(応用理学部門，環境地質学)。長野 県による新版長野県地質図作成事業では幹事長を 務める. 研究内容：地形地質発達と暮らしとの関 わり。本研究では, 現地調査・原稿執筆(地形地 質概説・廃坑の坑排水)を担当. E-mail : togashi-hitoshi@pref.nagano.lg.jp

科学論文では, 学説の検証可能性を保証することが重要です。そのため, 地質学雑誌掲載論文には, 重 要な証拠となつた試料がどこで得られたかを示しているものがあります。言うまでもないことですが, 見学や採取を行う場合, 各自の責任において地権者や関係官庁への連絡と許可の取得の必要があること にご注意下さい. 詳しくは, 次のページをご覧ください.

http://www.geosociety.jp/publication/content0073.html 